\title{
1 Engineering Salinity Tolerance in Plants: Progress and Prospects
}

2 Shabir H. Wani ${ }^{1 *}$, Vinay Kumar ${ }^{2,3}$, Tushar Khare ${ }^{2}$, Rajasheker Guddimalli ${ }^{4}$, Maheshwari

3 Parveda $^{4}$, Katalin Solymosi ${ }^{5}$, Penna Suprasanna ${ }^{6}$, Kavi Kishor PB ${ }^{4}$

$4{ }^{1}$ Mountain Research Centre for Field Crops, Khudwani, Anantnag-192 101, Sher-e-Kashmir

5 University of Agricultural Sciences and Technology of Kashmir, J\&K, India, ORCiD: 0000-

$6 \quad 0002-7456-4090$

$7 \quad{ }^{2}$ Department of Biotechnology, Modern College, Savitribai Phule Pune University, Ganeshkhind,

8 Pune 411016 , India,

$9{ }^{3}$ Department of Environmental Science, Savitribai Phule Pune University, Ganeshkhind, Pune

10411 016, India ORCiD: 0000-0002-9569-2411

$11{ }^{4}$ Department of Genetics, Osmania University, Hyderabad 500 007, India

$12{ }^{5}$ Department of Plant Anatomy, Institute of Biology, ELTE - Eötvös Loránd University,

13 Budapest 1053, Hungary, ORCiD: 0000-0001-5246-2547

$14{ }^{6}$ Nuclear Agriculture and Biotechnology Division, Bhabha Atomic Research Centre, Trombay,

15 Mumbai 400 085, India, ORCiD: 0000-0002-6572-6190

17 Running Title: Biotechnology for plant salinity tolerance

19 *Corresponding author:

20 Shabir Hussain Wani

$21{ }^{1}$ Mountain Research Centre for Field Crops, Khudwani, Anantnag-192 101, Sher-e-Kashmir

22 University of Agricultural Sciences and Technology of Kashmir, J\&K, India, ORCiD: 0000$23 \quad 0002-7456-4090$

24 shabirhussainwani@gmail.com

25 Phone: +917006907220

\section{Abstract}

29 Soil salinity exerts significant constraints on global crop production, posing a serious challenge

30 for plant breeders and biotechnologists. The classical transgenic approach for enhancing salinity

31 tolerance in plants revolves by boosting endogenous defence mechanisms, often via a single gene 
32 approach, and usually involves the enhanced synthesis of compatible osmolytes, antioxidants, 33 polyamines, maintenance of hormone homeostasis, modification of transporters and/or 34 regulatory proteins, including transcription factors (TFs) and alternative splicing events. 35 Occasionally, genetic manipulation of regulatory proteins or phytohormone levels confers 36 salinity-tolerance, but all these may cause undesired reduction in plant growth and/or yields. In

37 this review, we present and evaluate novel and cutting-edge approaches for engineering salt 38 tolerance in crop plants. First, we cover recent findings regarding the importance of regulatory 39 proteins and transporters, and how they can be used to enhance salt tolerance in crop plants. We 40 also evaluate the importance of halobiomes as a reservoir of genes that can be used for 41 engineering salt-tolerance in glycophytic crops. Additionally, the role of microRNAs as critical 42 post-transcriptional regulators in plant adaptive responses to salt stress are reviewed and their use 43 for engineering salt-tolerant crop plants is critically assessed. The potentials of alternative 44 splicing mechanisms and targeted gene-editing technologies in understanding plant salt-stress 45 responses and developing salt-tolerant crop plants is also discussed.

\section{Keywords}

48 CRISPR/Cas9, halobiome, ion transporters, microRNAs, regulatory elements, salinity stress, 49 transcription factors 


\section{Introduction}

53 Extreme soil salinity is one of the most destructive abiotic stresses for global agriculture as it can

54 lead to the degradation of arable soils, particularly those that are heavily irrigated (Akram et al.

55 2017; Kumar et al. 2017a). Over 800 million ha of land are estimated to be affected by salinity

56 worldwide and 32 million ha of dryland agriculture is thought to be salt-affected (FAO 2015).

57 Salinity stress drastically reduces agricultural productivity via adverse impacts on seed

58 germination, plant growth and development, plant vigour and crop yields (Cheeseman 2015).

59 The reduced plant growth caused by high soil salinity is due to salinity-induced water stress,

60 oxidative stress, nutritional imbalances, ion toxicity, membrane disorganization, reduced cell

61 division and expansion, disruption of key metabolic processes, and genotoxicity. The goal of

62 most studies dealing with salinity tolerance is to boost the capacity of crop plants to maintain

63 growth and productivity when cultivated on saline soils (Cao et al. 2018; Kumar et al. 2018). As

64 salinization of cultivated land is an increasing global problem, understanding the biological

65 impacts of salt exposure on plants and the development of salt-tolerant crop plants is urgently

66 required (Munns et al. 2012; Latef et al. 2017; Nguyen et al. 2017). Of the various approaches

67 that have been and are being utilized to enable crop production in salinity affected areas, crop

68 improvement by breeding is perhaps one of the best strategies to accomplish this goal. The use of

69 conventional plant breeding methods resulted in significant yield improvement in some crops

70 when grown on saline soils and this resulted in the development of salinity-tolerant crops.

71 However, conventional plant breeding approaches are most often lengthy, laborious and are

72 dependent on access to germplasm with sufficient genetic variability (Wani et al. 2016). For

73 some crops, genetic engineering strategies provide a viable alternative to conventional plant

74 breeding and are now becoming more widely used throughout the world to produce salt-tolerant 75 cultivars.

76 In the past few decades, plant genetic engineering approaches for the production of salt77 tolerant plants revolved around manipulating single genes from a diverse range of metabolic 78 pathways, including compatible-solute synthesis, ion-homeostasis and antioxidant 79 synthesis/metabolism, as well as signaling/regulatory elements including transcription factors 80 (TFs) (Cabello et al. 2014; Zhang et al. 2016). Although these single-gene manipulation 81 strategies achieved some success, both strategies have disadvantages and limitations. Single-gene 82 manipulation does not seem to be ideal because salinity tolerance is a complex trait probably 
83 influenced by several genes and factors concomitantly. On the other hand, modifying signaling 84 and regulatory pathways requires precise and detailed knowledge on their functioning, and often 85 plants with improved tolerance do not perform well under unstressed conditions. In contrast to 86 drought, soil salinity is a stressor that is constantly present in the soil, however, the intensity of

87 the stress as well as the response of the plants at different developmental stages or organs also 88 greatly varies. Therefore, identifying novel approaches to produce salt-tolerant plants, such as 89 co-expression of multiple-genes, epigenetic control of gene-expression and targeting post90 transcriptional modifications (small/micro-RNAs) are required (Shriram et al. 2016; Kumar et al. 91 2017b). Although many reviews were published focusing on transgenic strategies that can

92 potentially be used to produce salt-tolerant crop plants, in this review, we discuss and critically 93 evaluate from a practical perspective both developments in conventional plant breeding and 94 novel genetic engineering methods that can be used to develop salt-tolerant crops. Besides 95 evaluating the potential genes from various metabolic pathways that confer salt-tolerance in both 96 model and crop plants, we also discuss how genetic modification of signalling/regulatory 97 elements (including TFs), epigenetic control of gene-expression, post-transcriptional modifications (small/micro-RNAs), and genome editing technologies help to produce plants with 99 targeted genetic engineering (CRISPR-Cas).

100

\section{Engineering regulatory elements for increased salt tolerance}

102 As plants live in highly variable environments, they have evolved mechanisms that enable them 103 to rapidly respond to changing environmental conditions including soil salinity. It is necessary to 104 understand these mechanisms at the whole-plant, organ, tissue, cellular, physiological and 105 molecular levels. When plants encounter adverse conditions such as salinity, a variety of genes 106 with various functions can be upregulated or downregulated, and any resultant changes in 107 developmental and/or physiological processes can contribute to stress tolerance (Tran and 108 Mochida 2010; Mochida et al. 2011). While some of these upregulated or downregulated genes 109 encode proteins that play critical roles in stress associated growth or metabolic changes, many 110 other genes encode regulatory proteins such as TFs, which control salt-sensing and signal 111 transduction pathways and the expression of a range of salinity stress-responsive genes (Gupta 112 and Huang 2014; Li and Tran 2017; Mann et al. 2019). TFs play a vital role in connecting the 113 salt-sensory pathways to the various genes required for plant salt-tolerance (Nishiyama et al. 
114 2012). These genes play critical roles in regulating plant stress responses, to various abiotic 115 stress factors including salinity (Joshi et al. 2016; Wang et al. 2016a). Several studies reported 116 the development of transgenic plants with modified TF expression that improved salt-tolerance 117 (Joshi et al. 2016). Also, the TF families ERF/AP2, bZIP, MYB, MYC, NAC, WRKY, and zinc118 finger proteins were shown to have regulatory roles associated with plant stress-responses 119 (Kazan, 2015; Sun et al. 2016).

120 As demonstrated in many studies of various plant species, stress-responsive TFs function 121 in conjunction with the promoter regions to regulate the expression of salt-stress responsive 122 genes involved in salt-tolerance. For example, transgenic Oryza sativa lines over-expressing 123 OsDREB2A were relatively tolerant to salinity compared to their wild-type counterparts 124 (Mallikarjuna et al. 2011). Expression of the rice TF SALT-RESPONSIVE ERF1 (SERF1), 125 resulted in root-specific stimulation in response to salt and hydrogen peroxide $\left(\mathrm{H}_{2} \mathrm{O}_{2}\right)$ treatments 126 (Schmidt et al. 2013). In the absence of SERF1, disruption of a salinity-induced MAPK cascade 127 involved in acquisition of salt-tolerance occurs. It was shown that SERF1 binds to the promoters 128 of MAP3K6, MAPK5, DREB2A, and ZFP179 genes, and constitutive overexpression of SERF1 129 enhances salinity tolerance in rice plants (Schmidt et al. 2013). In addition, transgenic 130 Arabidopsis plants expressing TF gene OSAP21 and SbAP37 exhibited better growth than wild131 type plants under salt/drought/temperature stress conditions (Jin et al. 2013; Maheshwari et al. 132 2017). In a similar study, the $H h B R E B 2$ gene belonging to AP2/EREBP TF family was isolated 133 from Halimodendron halodendron. This gene was placed into the A-5 cluster of the DREB 134 subfamily, on the basis of its similarity to the AP2/ERF domain. Overexpression of the 135 HhBREB2 gene in Arabidopsis led to increased salt and drought tolerance in the transgenic 136 plants, thus providing evidence that HhBREB2 is an important TF involved in the regulation of 137 salinity associated signalling in plants (Ma et al. 2015b).

138 MYB-type TFs play diverse roles in plant development and plant responses to abiotic 139 stress. Transgenic rice plants overexpressing OsMYB2, an R2R3-type MYB gene, were more 140 tolerant to salt, cold, and dehydration than wild-type plants (Yang et al. 2012). OsMYB2141 overexpressing plants accumulated greater amounts of soluble sugars and proline, and exhibited 142 enhanced upregulation of genes encoding proline synthesis and transporter proteins than wild143 type plants. Greater upregulation of stress-related genes such as OsLEA3, OsRab16A and $144 O_{s} D R E B 2 A$, were noticed in OsMYB2-overexpressing plants. Besides, overexpression of 
145 OsMYB48-1, a novel MYB-related TF in rice plants, enhanced the tolerance to drought stress 146 imposed by mannitol and PEG, and to salinity stress (Xiong et al. 2014). It was shown that the 147 ARS1 gene, which encodes an R1-MYB type TF, had increased expression in the leaves of salt 148 stressed tomato plants and that the role of ARS1 was related to reduced transpirational water loss 149 in plants under salinity stress (Campos et al. 2016). Another family of TFs shown to be involved 150 in salt-tolerance are the NAC proteins (NAM, no apical meristem; ATAF, Arabidopsis 151 transcription activation factor and CUC, Cup-shaped cotyledon). This TF mega-family was one 152 of the first plant-specific TF families to be identified and in addition to their involvement in the 153 regulation of plant development, NAC proteins are believed to be involved in various abiotic 154 stress responses, including salinity and drought (Tran et al. 2010; Rahman et al. 2016). The role 155 of the rice $S N A C 1$ gene was investigated using transgenic wheat where the $S N A C 1$ gene was 156 placed under the control of a maize ubiquitin promoter (Saad et al. 2013). It was concluded that 157 drought and salt-tolerance were enhanced in these transgenic wheat plants (Saad et al. 2013). A 158 NAC gene from wheat was also characterized for a possible role in drought, salinity and freezing 159 tolerance, where a TaNAC67-GFP gene fusion was introduced into Arabidopsis under the 160 control of $C a M V-35 \mathrm{~S}$ promoter and transgenic plants were examined at both physiological and 161 morphological levels under various abiotic stresses (Mao et al. 2014). These transgenics showed 162 improved tolerance to drought, salt and freezing stresses (Mao et al. 2014). In another study, 163 TaNAC29 isolated from wheat was introduced into Arabidopsis using the Agrobacterium 164 tumefaciens-mediated floral dip method (Huang et al. 2015). The greenhouse-grown transgenics 165 showed enhanced tolerance to salt and drought stresses (Huang et al. 2015). Likewise, SNAC1 166 gene from rice was transferred using A. tumefaciens into Boehmeria nivea and the resulting 167 transgenics displayed increased tolerance towards salt and drought stresses, both at the seedling 168 and fiber maturation stages (An et al. 2015). A classic stress-responsive NAC TF CarNAC4 from 169 chickpea was characterized and its function was studied in transgenic Arabidopsis. Transgenics 170 exhibited enhanced tolerance to drought and salinity, by stimulating other stress-responsive 171 genes including RD29A, ERD10, COR15A, COR47, KIN1 and DREB2A (Yu et al. 2016), thus 172 confirming the role of CarNAC4 as a TF involved in the regulation of salt and drought stresses. 173 Thus, the above studies confirmed the importance of $N A C$ genes in salinity and drought stress 174 tolerance. However, genetic engineering of stress related regulatory networks can result in salt 175 and drought tolerance in crop plants, but this approach has the potential to cause pleiotropic 
176 effects and reduce yields in plants grown in the absence of stress or eventually in the presence of

177 other (e. g. biotic) stresses. Moreover, these methods have the disadvantage of not yet available

178 for several important crops including wheat (Triticum aestivum). To overcome any potentially

179 negative impacts associated with engineering, TFs alongside the use of conditional or tissue-

180 specific promoters should be considered (Cabello et al. 2014). In addition, methodological

181 developments have to be achieved in case of genetically and molecularly more challenging

182 crops.

\section{Manipulating ion transport and transporters}

185 Salt stress impacts plant growth and crop productivity by causing hyperosmotic stress, resulting

186 in decreased water potential which limits water uptake and thus cell expansion, and on a longer 187 time-scale by hyperionic stress, i.e. toxicity due to excess $\mathrm{Na}^{+}$and $\mathrm{Cl}^{-}$ion concentrations 188 (Maathuis et al. 2014). While $\mathrm{Cl}^{-}$is an essential micronutrient, it can be toxic to plants at higher 189 concentrations (Khare et al. 2015). Information on $\mathrm{Cl}^{-}$transport and genetic engineering 190 specifically for $\mathrm{Cl}^{-}$tolerance is inadequate and so is not discussed below. Although the 191 mechanisms involved in plant salt-tolerance are not yet fully understood, it is clear that the 192 control of water movement through aquaporin channels (Martinez-Ballesta and Carvajal 2014), 193 and ion transport and transporters play crucial roles in plant salt-tolerance and that the 194 mechanisms that regulate water and ion transport may be suitable targets for the production of 195 salt tolerant crops (Rahman et al. 2017). $\mathrm{Na}^{+}$and $\mathrm{Cl}^{-}$ions are first taken up by the outer root 196 cells, then transported to the root xylem and finally from the root to the shoot, where they may be 197 stored in vacuoles or in the apoplastic space, or possibly recirculated back to the root system or 198 to older leaves that are less active (Figure 1). In some salt tolerant plant species, $\mathrm{Na}^{+}$and $\mathrm{Cl}^{-}$ions 199 can also be excreted via special structures, which take the form of glands or bladders (Shabala et 200 al. 2014). Salt-tolerance mechanisms also include mitigation of the effects of ion-induced stress 201 by the production of osmoprotectants and compatible solutes (glycine betaine, mannitol, 202 ononitol, trehalose, polyamines), proteins (stress and heat shock proteins, late embryogenesis 203 abundant proteins, signalization and hormone modulating factors), antioxidants and antioxidant 204 enzymes that prevent oxidative damage (Gupta and Huang 2014). However, production of the 205 above can have high energy costs and thus reduce the crop yields. Key factors associated with 206 the prevention of ion toxicity under salt stress are (i) restriction of $\mathrm{Na}^{+}$and $\mathrm{Cl}^{-}$uptake, (ii) 
restriction of $\mathrm{Na}^{+}$and $\mathrm{Cl}^{-}$transport (iii) maintenance of beneficial ion homeostasis e.g. that of $\mathrm{K}^{+}$,

208 which is an essential nutrient for plant growth and development. For example, a high $\mathrm{K}^{+} / \mathrm{Na}^{+}$ 209 ratio can be maintained by inhibition of $\mathrm{NaCl}$-induced $\mathrm{K}^{+}$efflux from the cytoplasm (Kumar and 210 Khare 2016).

211 Although the biochemical and biotechnological targeting of the $\mathrm{Na}^{+}$uptake system of plants at 212 the root level (i.e. soil-epidermis interface) would seem very promising, there are only few 213 attempts related to it. This is probably due to (i) the complexity of $\mathrm{Na}^{+}$uptake involving several 214 not well characterized components like non-selective cation channels (NSCC) and high-affinity 215 potassium transporters (HKT) and (ii) its interference with the uptake of other essential cations, 216 especially $\mathrm{K}^{+}$(e.g. at $A K T 1$, AtHAK5 transporters). The passive influx of $\mathrm{Na}^{+}$into the cytoplasm 217 cannot be fully prevented under salt stress; therefore, other salt tolerance mechanisms evolved in 218 plants to decrease ion toxicity within the cells. These include its (i) active export (futile cycling) 219 from root cells by plasma membrane (PM) $\mathrm{Na}^{+} / \mathrm{H}^{+}$antiporters (e.g. SOS1, NHA1 or NHXLP), or 220 its (ii) exclusion from the cytoplasm to other intracellular compartments (like vacuoles, plastids 221 or endosomes) with the help of NHX-type vacuolar $\mathrm{Na}^{+}\left(\mathrm{K}^{+}\right) / \mathrm{H}^{+}$antiporters both at the root and 222 the shoot (especially leaf) level or both mechanisms (Tables 1 and 2). The SOS system also has 223 important roles in the complex regulatory networks activated under stress (Ji et al. 2013). PM 224 located $\mathrm{H}^{+}$-ATPases (e.g. AHA1/2/3 - Figure 1) and $\mathrm{H}^{+}$-pyrophosphatases (Wang et al. 2016b) 225 are important to regulate ion uptake at the root level or exclusion in leaf mesophyll cells. In 226 many species salt tolerance mechanisms also include long-distance transport processes or 227 especially their inhibition (Figure 1).

228 This review focuses on recent studies that involve the genetic modification of plants with single 229 or multiple ion transport components to improve salt tolerance (Figure 1; Tables 1 and 2). For $230 \mathrm{Na}^{+}$and $\mathrm{Cl}^{-}$transport and transporters in plants following reviews give excellent information 231 (Hasegawa 2013; Maathuis et al. 2014; Nieves-Cordones et al. 2016; Almeida et al. 2017). Most 232 of the transporters have tissue- and organ-dependent expression patterns in many species. 233 Several homologs of them (e.g. $N H X$ and $H K T$ ) are present and differently expressed in various 234 intracellular compartments, and the expression of different transport components is often 235 mutually regulated in a complex manner (Plett et al. 2010; Yadav et al. 2012; Gouiaa and 236 Khoudi, 2015; Ma et al. 2017; Hamamoto et al. 2015; Almeida et al. 2017) and also depending 237 on the developmental stage and the strength of the stress (Zhang et al. 2017). Therefore, the 
exact impact of genetic engineering of transport components needs to be carefully assessed and analyzed for each species and in the complex context of plant nutrition.

\subsection{Membrane transport and salt stress tolerance}

242 PM proton $\left(\mathrm{H}^{+}\right)$-ATPases, vacuolar membrane $\mathrm{H}^{+}$-ATPases, PM and vacuolar membrane $\mathrm{H}^{+}$243 pyrophosphatases $\left(\mathrm{H}^{+}\right.$-PPases $)$constitute proton pumps in plants. Besides proton pumps, $\mathrm{Na}^{+}$and

$244 \mathrm{~K}^{+}$transporters also play a vital role during salt stress tolerance. Their functions and the 245 transgenics developed utilizing these genes are briefly described below.

\subsubsection{Proton pumps and salt stress tolerance}

248 Plant $\mathrm{H}^{+}$pumps play primary roles for the transport of ions and solutes across cell membranes. In 249 plants, three major $\mathrm{H}^{+}$transport proteins $\left[\mathrm{PM} \mathrm{H} \mathrm{H}^{+}\right.$-ATPase, vacuolar $\mathrm{H}^{+}$-ATPase and PM and 250 vacuolar $\mathrm{H}^{+}$-pyrophosphatases (later called VPPases)] were detected and found to be associated 251 with salt stress tolerance. It is known that $\mathrm{H}^{+}$-pumps produce an electrochemical potential 252 gradient which is the motive force that is essential for root nutrient uptake, stomatal aperture, 253 phloem loading and cell growth (Blumwald et al. 2000; Gaxiola et al. 2007; Mansour 2014).

\subsubsection{Plasma membrane $\mathrm{H}^{+}$-ATPase}

256 PM H $\mathrm{H}^{+}$-ATPases or P-type ATPases (P-ATPases) are encoded by a large gene family. These 257 transporters couple ATP hydrolysis with $\mathrm{H}^{+}$transport at the membrane level (Gaxiola et al. 2007, 258 Fuglsang et al. 2010). Mansour (2014) noticed that high activity of P-ATPase under salt stress 259 repolarizes the $\mathrm{NaCl}$-induced depolarization of $\mathrm{PM}$ and is associated with salt stress tolerance. 260 Indeed, higher P-ATPase enzyme activity and salt stress tolerance was noticed in halophytes 261 (Mansour 2014). Sun et al. (2009) pointed out P-type ATPases reduce $\mathrm{Na}^{+}$influx and $\mathrm{K}^{+}$efflux 262 and maintain proper $\mathrm{K}^{+} / \mathrm{Na}^{+}$levels and is also associated with the movement of stomatal aperture 263 (Zhang et al. 2001; Gaxiola et al. 2007). Bose et al. (2015) found out that PM $\mathrm{H}^{+}$-ATPase 264 activity is higher in halophytes in comparison with glycophytes under salt stress conditions 265 indicating its role in salinity tolerance. Vitart et al. (2001) observed a reduction in growth in a 266 PM H$~^{+}$-ATPase aha4 mutant Arabidopsis when exposed to salt stress. Gevaudant et al. (2007) 267 demonstrated increased salt tolerance in transgenic tobacco plants expressing a $\mathrm{PM} \mathrm{H}^{+}$-ATPase, 268 lacking the auto-inhibitory domain. However, the ubiquitous and not tissue specific expression of 
the active proton pump only increased salt tolerance during germination and early growth of 270 seedlings, and caused altered development of the adult plants (Gevaudant et al. 2007) and cell 271 expansion in another experiment (Niczyj et al. 2016), and thus does not represent a promising 272 tool to develop salt tolerant crops. A PM $\mathrm{H}^{+}$-ATPase4 gene (PMA4) isolated from Nicotiana 273 plumbaginifolia when overexpressed in tobacco showed no difference in growth under normal 274 conditions, but, impaired sucrose translocation, stomatal opening, plant growth and male fertility 275 were noticed when the endogenous and the transgene PMA4 were co-suppressed (Zhao et al. 276 2000). Zhang et al. (2014) overexpressed the $\mathrm{PM} \mathrm{H}^{+}$-ATPase of the salt-tolerant Chloris virgata 277 (ChvPMA and ChvPMASC) in genetically modified yeast and found enhanced resistance to salt 278 and lower $\mathrm{pH}$ conditions. Moreover, the yeast overexpressing ChvPMAAC displayed better 279 growth than ChvPMA at an external $\mathrm{pH} 4.0$ in the presence of $\mathrm{NaCl}$. Transgenic A. thaliana 280 containing the transgene ChvPMAAC exhibited better root growth than plants containing 281 ChvPMA in the presence of $\mathrm{NaCl}$ stress (Zhang et al. 2014). Recently, Fan et al. (2018) 282 overexpressed a $\mathrm{PM} \mathrm{H}^{+}$-ATPase (SpAHA1) isolated from the halophyte Sesuvium portulacastrum 283 in Arabidopsis thaliana that conferred salt tolerance by improving seed germination ratio, root 284 growth, and biomass of transgenics. In addition to improved ion homeostasis, transgenic plants 285 displayed lower oxidative stress (Fan et al. 2018). The above studies indicate the important yet 286 not fully understood roles of $\mathrm{PM} \mathrm{H}^{+}$-ATPase in imparting salt stress tolerance.

\subsubsection{Vacuolar membrane $\mathrm{H}^{+}$-ATPase (V-ATPase)}

290 (V1 and V0) that help in $\mathrm{H}^{+}$translocation (Gaxiola et al. 2007). Jiang et al. (2010) and Bassil and 291 Blumwald (2014) noted that V-ATPase provides the driving force for the vacuolar 292 compartmentalization of $\mathrm{Na}^{+}$. V-ATPase is highly abundant in the tonoplast and its activity is 293 modulated in order to cope with environmental changes (Ratajczak 2000). Enhanced V-ATPase 294 activity as well as upregulation of transcript levels of some subunits was reported under salt 295 stress by Kirsch et al. (1996) and Silva and Geros (2009). Klychnikov et al. (2007) found out that 296 14-3-3 proteins (activators of PM ATPases) interact with some of the subunits (VHA-A) in a 297 phosphorylation dependent way in Hordeum vulgare for the regulation of V-ATPase activity. 298 Dietz et al. (2001) showed the functional significance of V-ATPase in the ability of plants to 299 show resistance to abiotic stress. Golldack and Dietz (2000), Baisakh et al. (2008) demonstrated 
upregulation of V-ATPase during early stages of salt stress indicating its involvement in the process. In response to salt stress, $V H A-A$ transcript was upregulated in tobacco (Narasimhan et al. 1991), sugarbeet (Lehr et al. 1999) and wheat (Golldack et al. 2001). Higher transcript levels of VHA-B were noticed under salt stress in Mesembryanthemum crystallinum (Golldack and Dietz 2000), and wheat (Wang et al. 2011). Likewise, VHA-C gene was found triggered by salt stress in M. crystallinum (Kluge et al. 2003), and Pennisetum glaucum (Tyagi et al. 2005). However, studies on the role of orthologous expression of genes encoding V-ATPase subunits on the ability of plants to withstand salt stress are scarce though RNAi mutants were studied by Padmanaban et al. (2004). Gaxiola et al. (2001) pointed out that overexpression of $V H A$ would not be easy since it consists of multisubunit complex that needs to be expressed at the correct level. Baisakh et al. (2012) showed enhanced salt stress tolerance of rice transgenics expressing a vacuolar $\mathrm{H}^{+}$-ATPase subunit c1 (SaVHAcl) gene from the halophyte grass Spartina alternifolia.

312 They noticed high accumulation of $\mathrm{Na}^{+}$levels in roots and leaves, and yet the plants were not 313 affected by the toxic $\mathrm{Na}^{+}$ions. This could be due to the sequestration of $\mathrm{Na}^{+}$ions at the tonoplast 314 by $\mathrm{Na}^{+}-\mathrm{H}^{+}$-antiporter that was energized by a proton motive force created by the overexpression 315 of the above gene as pointed out by Apse et al. (1999). Schumacher et al. (1999) demonstrated 316 that V-ATPase is involved in plant development and signaling as evident from the V-ATPase 317 mutant, det3, which reduced subunit C transcript. Xu et al. (2011), Wang et al. (2011) and Zhang 318 et al. (2014b) overexpressed subunit $C 1$ of VHA from Limonium bicolor, subunits $B$ and $E$ of 319 VHA from Triticum aestivum, respectively, and found improved salt tolerance in tobacco (Xu et 320 al. 2011) and Arabidopsis (Wang et al. 2011; Zhang et al. 2014b). It is clear from the studies of 321 Baisakh et al. (2012) that SaVHAcl (isolated from Spartina alterniflora) is involved in cell 322 expansion and maintenance of net photosynthesis (i.e. higher chlorophyll content in transgenics 323 in comparison with wild-type plants) with higher root and leaf growths and yields under salt 324 stress. Zhang et al. (2013) showed that RNAi-directed downregulation of vacuolar $\mathrm{H}^{+}$-ATPase 325 subunit- $\alpha$ results in enhanced stomatal aperture and density in rice. He et al. (2014) reported high 326 expression levels of $A, C, D, F$ and $\alpha$-subunits under salt stress conditions. They also overexpressed wheat $\mathrm{V}-\mathrm{H}^{+}$-ATPase subunit genes that imparted salt tolerance significantly to the 328 transgenic Arabidopsis thaliana plants. Further, Dong et al. (2015) found that ectopic expression 329 of subunit $A$ of $M d V H A-A$ (vacuolar $\mathrm{H}^{+}$-ATPase subunit A) isolated from Malus domestica 330 enhanced the salt tolerance in tobacco. Wang et al. (2016a) showed that overexpression of a 
331 vacuolar-type HC-ATPase C subunit gene from Iris lactea (IrlVHA-c), enhanced the salt 332 tolerance in tobacco. Liu et al. (2018) demonstrated that the gene encoding subunit A of the 333 vacuolar $\mathrm{H}^{+}$-ATPase from cotton $(G h V H A-A)$ plays an important role in conferring tolerance to 334 water deficit. The above studies also infer that the genes isolated from halophytes could be 335 effectively utilized for alleviating salt stress in the crop plants.

\subsubsection{PM and vacuolar membrane bound $\mathrm{H}^{+} \mathrm{PPases}$}

337 In plants, pyrophosphate (PPi) is produced as a by-product during the activation or 338 polymerization steps of many biosynthetic pathways. It is hydrolyzed by soluble 339 pyrophosphatase $\left(\mathrm{H}^{+}\right.$-PPase) enzyme in the plastids (Weiner et al. 1987). On the other hand, 340 cytosol of higher plants contains very little PPi. Zhen et al. (1997) found out that cytosolic PPi 341 acts as an energy source for energizing the vacuolar membrane via PPi-dependent proton pump. $342 \mathrm{H}^{+}$-PPases are hydrophobic single subunit proteins unlike that of PM and V-ATPases. They 343 generate $\mathrm{H}^{+}$gradient across the vacuole, Golgi and PM using the energy generated during 344 hydrolysis of PPi (Gaxiola et al. 2007). While Silva et al. (2009) showed that V-H - PPase 345 activity decreases when plants are exposed to salt stress, enhanced activity was also recorded in 346 several taxa (Parks et al. 2002; Queirós et al. 2009). $\mathrm{H}^{+}$-PPases are of two types (type I and type 347 II). For their activity, type $\mathrm{I}^{+}$-PPases require cytosolic $\mathrm{K}^{+}$and are sensitive to inhibition by $348 \mathrm{Ca}^{2+}$. On the other hand, type $\mathrm{II} \mathrm{H}^{+}$-PPases are insensitive to $\mathrm{K}^{+}$ions but $\mathrm{Ca}^{2+}$ sensitive. Type I $349 \mathrm{H}^{+}$-PPases acidify the vacuole (Gaxiola et al. 2007) and are also noticed in the PM 350 (Alexandersson et al. 2004). Maeshima (2000) showed that vacuolar $\mathrm{H}^{+}$-PPase activity is 351 upregulated under salt stress conditions. Gene that encodes vacuolar $\mathrm{H}^{+}$-pyrophosphatase 352 (VPPase) was cloned both from dicots (Arabidopsis) as well as monocots (Sorghum bicolor) and 353 overexpressed in diverse plants like Arabidopsis, finger millet etc. (Guo et al. 2006; Anjaneyulu 354 et al. 2014; Pizzio et al. 2015). Such transgenics displayed both salt and drought stress tolerance 355 (Sarafian et al. 1992, Gaxiola et al. 2001, Guo et al. 2006, Pizzio et al. 2015). The tolerance to 356 salt and water stresses in these transgenic plants is due to increased solute uptake into vacuoles 357 as evident from the measurements of $\mathrm{Na}^{+}$and $\mathrm{K}^{+}$ions (Anjaneyulu et al. 2014). The above 358 studies infer that VPPase is an important gene involved in $\mathrm{H}^{+}$translocation and abiotic stress 359 tolerance. The regulation of $\mathrm{V}-\mathrm{H}^{+}$-ATPase as well as $\mathrm{V}-\mathrm{H}^{+}$-PPase activities by salt stress is 360 reported, but correlative pattern is missing for activation or deactivation of these proton pumps in 361 response to salt stress and water deficit. It appears that P-ATPases, V-ATPases and $\mathrm{H}^{+}$-PPases 
362 are regulated by a common mechanism and 14-3-3 proteins are known to regulate many 363 membranes localized proteins such as ion pumps (Bunney et al. 2002). Taken together, all the 364 three ion pumps seem to play a pivotal role during salt stress in higher plants, but their 365 engineering is challenging (especially in case of the multisubunit V-ATPase). Also, their use to 366 improve crop yields under glasshouse or field conditions remains questionable.

\section{2 $\mathrm{Na}^{+}-\mathrm{H}^{+}$-antiporters (NHX), sodium-proton exchangers (NHE), and salt stress}

369 Transport of $\mathrm{Na}^{+}$into the plant cells is mediated by non-selective cation channels (NSCCs) that do not have selectivity for cations. Demidchik and Maathuis (2007) pointed out that these are permeable to many monovalent cations at the PM tonoplast level. NSCCs are of many types such

372 as depolarization-activated (voltage-dependent), hyper-polarization-activated (voltageindependent), reactive oxygen species (ROS)-activated NSCCs, amino acid-activated NSCCs,

374 cyclic nucleotide-gated (CNG) NSCCs, etc. Apse and Blumwald (2007) and Zhang et al. (2010) 375 suggest that $\mathrm{Na}^{+}$influx across the PM occurs via NSCC/VIC in root cortical cells.

376 NHX transporters are modulated by and hence associated with salt stress, long-distance transport 377 of $\mathrm{Na}^{+}$from root to shoot, protein targeting and trafficking and even functioning of stomata as 378 pointed out by Bassil et al. (2011a, 2011b), Barragan et al. (2012), and Wu et al. (2016). AtNHX1 379 is the first reported plant transporter that mediates $\mathrm{Na}^{+}$transport into vacuoles (Apse et al., 380 1999). Further, AtNHX1 or salt overly sensitive pathway (SOS) gene AtSOS1 overexpression in 381 tomato resulted in better salt tolerance (Apse et al. 1999, Shi et al., 2003). At the same, it was 382 shown that salt or $\mathrm{Na}^{+}$does not accumulate in the fruit, but accumulates only in the foliage of 383 tomato (Zhang and Blumwald, 2001; Shi et al., 2003). Liu and Zhu (1998) noticed that a calcium 384 sensor homolog is required for salt tolerance. Later, Liu et al. (2000) demonstrated that in 385 Arabidopsis thaliana, SOS2 gene encodes a protein kinase required for salt stress tolerance. 386 Subsequent studies revealed that the regulation of $\mathrm{Na}^{+} / \mathrm{H}^{+}$exchange in $A$. thaliana is carried out 387 by the SOS pathway (Qiu et al. 2004). Besides $N H X$ family members, $N H E$-type protein family 388 members (both PM and organellar membrane-bound) were identified in plants that may perform 389 regulation of intracellular $\mathrm{pH}$ and cell volume (Counillon and Pouyssegur 2000). The roles of all 390 NHX members ( 8 in most eukaryotes) during salt stress were amply demonstrated in many 391 transgenics (Apse et al. 1999; Apse and Blumwald 2007; Shi et al. 2008; Kronzucker and Britto 392 2011; Bassil et al. 2011a; Yadav et al. 2012). But the numbers of NHE members that exist in 
393 higher plants except in S. bicolor (9), the functions of $N H E$ family members (during salt stress), 394 and their tissue specific expressions are not completely known though redundant functions are 395 suggested. Recently, Kumari et al. (2018) showed that their tissue specific expressions under salt 396 and drought stress conditions in Sorghum bicolor, suggesting their tissue specific role during 397 abiotic stress. Further, $N H X$-like proteins were detected earlier, and one such protein bound to 398 the PM was isolated from S. bicolor and overexpressed in tomato (Kumari et al. 2017). 399 Transgenic tomato plants displayed better salt stress tolerance in comparison with wild-type 400 plants. But it is obscure how many such $N H X$-like proteins exist in higher plants, where they are 401 localized intracellularly and whether they have any role in development and abiotic stress 402 tolerance.

\subsubsection{Transport of $\mathrm{Na}^{+}$in chloroplasts and salt stress tolerance}

405 In $\mathrm{C}_{4}$ plants, $\mathrm{Na}^{+}$is transported into the chloroplasts for the synthesis of phosphoenolpyruvate 406 (PEP) for photosynthetic $\mathrm{CO}_{2}$ fixation. In $\mathrm{C}_{4}$ plants, a $\mathrm{Na}^{+}$/pyruvate symporter BASS2 (bile 407 acid/sodium symporter family protein 2), helps in co-transport of $\mathrm{Na}^{+}$and pyruvate (Figure 1). $408 \mathrm{Na}^{+}$is exported out by a sodium hydrogen antiporter NHD1 in such plants (Furumoto et al. 409 2011). On the other hand, in $\mathrm{C}_{3}$ plants, $\mathrm{Na}^{+}$accumulation in chloroplasts inhibits photosynthesis 410 and thus may be detrimental to their survival. Müller et al. (2014) used knock out mutants 411 (NHD1) of $A$. thaliana and demonstrated that such plants are not able to export $\mathrm{Na}^{+}$, 412 photosynthesis is impaired in them and they are unable to tolerate $\mathrm{NaCl}$ stress. This indicates that $413 \mathrm{Na}^{+}$homeostasis in chloroplasts may be important for plant survival as well as to their 414 photosynthetic activity and thus productivity and yield.

415 It appears that halophytes overcome stomatal limitation by switching to $\mathrm{CO}_{2}$ concentrating 416 mechanism under saline conditions. Number of chloroplasts also increases per cell in halophytes 417 and salt entry into chloroplast stroma appears necessary for the formation of grana and PSII 418 (Bose et al. 2017). Such a phenomenon has not yet been reported in glycophytes so far. 419 Halophytes accumulate more $\mathrm{Cl}^{-}$ions and use it in functional roles but not glycophytes. Several 420 studies characterized a total of 53 salt-responsive genes encoding chloroplast localized proteins. 421 This implies that multiple pathways like thylakoid membrane organization, activity of PS II, 422 assimilation of $\mathrm{CO}_{2}$, photorespiration, ROS scavenging, osmotic and ion homeostasis and ABA 
423 biosynthesis and signaling are triggered in chloroplasts in response to salt stress (Suo et al. 424 2017).

425 Tonoplast localized $\mathrm{K}^{+}$channel (TPK1) was found crucial for maintaining intracellular $\mathrm{K}^{+} / \mathrm{Na}^{+}$ 426 ratio in Arabidopsis. Latz et al. (2013) showed that salt stress triggers phosphorylation of the 427 Arabidopsis vacuolar $\mathrm{K}^{+}$channel TPK1 by calcium-dependent protein kinase $(C D P K)$ and 428 modulates cytosolic $\mathrm{K}^{+}$influx under $\mathrm{NaCl}$ stress conditions. Carraretto et al. (2016) 429 demonstrated that TPK3 is localized to the chloroplast membranes and mediates $\mathrm{K}^{+}$homeostasis, 430 an important event for plant fitness. It is essential for us now to understand the intricate 431 mechanisms how these transporters move both cations and anions such as $\mathrm{Na}^{+}, \mathrm{K}^{+}$and $\mathrm{Cl}^{-}$across 432 the chloroplast envelope membrane and thylakoids (reviewed in Szabó and Spetea 2017) and 433 their precise regulation of PSI and PSII activities under salt stress conditions.

\subsubsection{Potassium transporters and salt stress}

$436 \mathrm{~K}^{+}$is an essential nutrient for plant metabolism, therefore, the detrimental effects of salt stress 437 are often associated with disturbances in the $\mathrm{K}^{+}$uptake and thus intracellular $\mathrm{K}^{+}$homeostasis or 438 the $\mathrm{K}^{+} / \mathrm{Na}^{+}$ratio (Amtmann and Beilby 2010, Srivastava et al. 2020). PM located $\mathrm{H}^{+}$pumps are 439 involved in creating a $\mathrm{pH}$ gradient and thus contribute to the maintenance of membrane potential 440 providing the driving force for essential ion $\left(\mathrm{K}^{+}\right)$uptake through voltage-gated channels and also 441 for the exclusion of $\mathrm{Na}^{+}$in exchange for $\mathrm{H}^{+}$on plasma membrane located $\mathrm{Na}^{+} / \mathrm{H}^{+}$exchangers 442 such as SOS1 (Bose et al. 2015). On the other hand, voltage-independent channels with increased $443 \mathrm{~K}^{+} / \mathrm{Na}^{+}$selectivity and thus reduced $\mathrm{Na}^{+}$uptake may contribute to improved salt tolerance as 444 shown in the case of the 'salt excluder' Thellungiella salsuginea (previously T. halophila) when 445 compared with Arabidopsis, its glycophyte relative (Volkov et al. 2004; Volkov and Amtmann 446 2007, Amtmann and Beilby 2010). Biochemical and biotechnological targeting of these channels 447 to restrict $\mathrm{Na}^{+}$uptake is also beneficial for the $\mathrm{K}^{+} / \mathrm{Na}^{+}$homeostasis as it does not impact the 448 negative membrane potential and thus the selective uptake of $\mathrm{K}^{+}$via inward rectifying $\mathrm{K}^{+}$ 449 channels (Amtmann and Beilby 2010). Influx of $\mathrm{Na}^{+}$(or $\mathrm{K}^{+}$) into the root cells may also occur on 450 some members of the high-affinity potassium $\left(\mathrm{K}^{+}\right)$transporter $(H K T)$ family (Kronzucker and 451 Britto 2011). Data on cultivars with different salinity tolerance have shown that genetic 452 modification (i.e. partial deletion or point mutations, etc.) of HKT1 (now termed HKT2;1) may 
453 contribute to improved $\mathrm{K}^{+} / \mathrm{Na}^{+}$selectivity, altered activity and thus increased salt tolerance 454 (Cotsaftis et al. 2012).

455 Transgenic expression of a selective, $\mathrm{K}^{+}$-inward-rectifying channel (KIRC) of the halophyte 456 Puccinellia tenuis (PutAKT1) in Arabidopsis resulted in decreased shoot and root $\mathrm{Na}^{+}$content 457 and thus enhanced salt tolerance (Ardie et al. 2010), while under salt stress the level of $A K T 1$ 458 expression was in general downregulated especially in salt excluder cultivars (Golldack et al. 459 2003, Fuchs et al. 2005). These and other data (Wang et al. 2007) indicate that some halophytes 460 can tolerate salt by being able to maintain high $\mathrm{K}^{+}$uptake and simultaneously restrict $\mathrm{Na}^{+}$influx 461 to the root cells (Ardie et al. 2010).

462 Taken together, a high number of ion transport components (alone or simultaneously with other 463 components) have been genetically modified to improve salt tolerance (Tables 1, 2). However, 464 no GM crop has been commercialized on the basis of these data (Fita et al. 2015). This is due to 465 the fact, that complex interactions, mutual and tissue- or cell-specific regulations and 466 competitions of the uptake systems of essential ions need to be considered and may all need to be 467 targeted individually or simultaneously but specifically for enhanced salt tolerance. Therefore, 468 due to the complex nature of plant ion homeostasis and regulatory networks that operate it, the 469 development of transgenics or crop plants with better tolerance is quite challenging and not very 470 promising at the moment in this field.

\subsection{RNA interference (RNAi) technologies for the production of salt-tolerant plants}

473 RNAi is a biological process by which small RNA (sRNA) molecules stop the translation of 474 targeted mRNAs and thereby inhibit or alter gene expression. RNAi is regarded as an important 475 mechanism involved in the post-transcriptional regulation of gene expression in plants (Shriram 476 et al. 2016; Kumar et al. 2017b). Plants have evolved a complex set of interfering non-coding 477 RNA (ncRNA) species, including the microRNAs (miRNAs) and small interfering RNAs 478 (siRNAs), to silence targeted genes very precisely and without affecting the expression of other 479 genes. In this review, only miRNAs are covered. These small ncRNAs are the products of 480 dsRNAs cleaved by DICER or DCL enzyme-mediated systems. ncRNAs when coupled with 481 RISC and argonaute proteins lead to RNAi (Saurabh et al. 2014). RNA mediated gene silencing 482 plays pivotal roles in orchestrating the expression, stability and inheritance of plant genomes, as 483 well as in defenses against biotic and abiotic stressors. Numerous investigations demonstrated 
484 that RNAi can function as a master regulator of the regulatory networks associated with the 485 expression of stress related genes (Sunkar et al. 2012; Lotfi et al. 2017). Selected salt responsive 486 plant miRNAs, their targets and the traits regulated by the respective miRNAs are presented in

\section{Figure 2.}

488 RNAi is emerging as a powerful tool for targeted gene silencing or as a means to alter gene 489 expression for the improvement of crop plants. Owing to the development of other genomic tools 490 such as deep sequencing and degradome analysis, coupled with computational tools, an 491 increasing number miRNAs involved in growth/developmental processes, and stress-responses in 492 plants are being identified and analysed for their functionality. Major databases and 493 computational tools to identify miRNAs and predict their target genes are presented in Table 3. 494 Approaches to regulate the expression of genes by the overexpression or knock-down of specific 495 miRNAs offer a novel and potentially effective approach to engineer salinity tolerance into crop 496 plants are gaining momentum (Zhang 2015; Khare et al. 2018). Recent studies have confirmed 497 that manipulating miRNA gene(s) significantly improves crop plant tolerance to environmental 498 stresses (Leng et al. 2017; Yang et al. 2017). Over-expressing or repressing stress responsivemiRNAs or their targets, miRNA-resistant target genes and miRNAs all have potential for

500 increasing the stress tolerance of crop plants. Overexpression of the gma-miR172 transcript 501 improved salt tolerance of Arabidopsis plants, with higher germination and cotyledon greening 502 rates, and longer roots ( $\mathrm{Li}$ et al. 2015). Transgenic plants showed 73-78\% germination rate, with $50372-77 \%$ seedlings turning green, at $150 \mathrm{mM} \mathrm{NaCl}$. In contrast, wild-type plants showed only $50463 \%$ germination and 57.6\% greening rates, at the same $\mathrm{NaCl}$ level (Li et al. 2015) and it has 505 been demonstrated that salt stress inhibits chlorophyll biosynthesis (Abdelkader et al. 2007). Pan 506 et al. (2016) reported roles for $m i R 172 a$ in enhanced salinity tolerance and long-distance stress 507 signalling. They investigated the growth of miR172a hairy root lines and miR172a deficient lines 508 under $200 \mathrm{mM} \mathrm{NaCl}$ salt stress. Overexpression of osa-miR528 in transgenic Agrostis stolonifera 509 resulted in shortened internodes, a higher number of tillers, better water retention, membrane 510 integrity, and $\mathrm{K}^{+}$homeostasis, improved salt tolerance and higher antioxidant enzyme activities 511 compared to wild-type plants (Yuan et al. 2015). Furthermore, ectopic expression of miR398 512 genes was associated with oxidative stress tolerance in grapevine (Leng et al. 2017). In contrast, 513 Yang et al. (2017) showed that the overexpression of $o s a-m i R 171 c$ reduced the salt tolerance of 514 transgenic rice. These authors concluded that osa-miR171c was involved in the regulation of 
515 stomatal development, several physiological changes, the expression of stress-related genes and 516 ABA-dependent signalling pathways, and that it was by regulating these processes that osa517 miR171c influenced the salt tolerance of rice (Yang et al. 2017). The above studies demonstrate 518 the potential of miRNA-based manipulations to enhance plant salt-tolerance and the fact that 519 genes encoding miRNAs represent potential targets for engineering salt tolerance in glycophytic 520 crop plants. However, further research is required to field evaluate these transgenics for their

521 yield potential and also to better understand species-specific differences in miRNA-transformed 522 transgenic plants.

\section{5. QTLomics of salt tolerance}

525 Identification and analysis of quantitative trait loci (QTL) has progressed phenomenally towards marker development and crop breeding applications (Ismail and Horie 2017; Cobb et al. 2019). It

527 has become feasible to characterize at the molecular level the genes involved in novel traits 528 associated with abiotic stress tolerance, especially salt tolerance. This has become possible 529 owing to the extensive physiological and molecular studies on tolerance to various abiotic (ionic 530 and/or osmotic stresses) and information gateway on stress specific as well as shared stress 531 adaptation mechanisms. Successful efforts have been made for the identification of important, 532 novel QTLs in rice, cotton, soybean and other crops. A significant finding has been the 533 identification of salt-tolerance associated QTLs, especially seedling stage Saltol QTL which is 534 associated with $\mathrm{Na}^{+} / \mathrm{K}^{+}$homeostasis under salt stress (Ren et al. 2005; Thompson et al. 2010). 535 Another QTL which is contained within Saltol is the SKC1 associated with shoot $\mathrm{K}^{+}$ concentration (Ren et al. 2005). In rice, a QTL, Saltol, was inrrogressed into an elite salinity

537 sensitive rice cv Pusa Basmati 1121 for achieving seedling-stage salt stress tolerance. The newly

538 bred line showed superior agronomic performance and better seedling stage tolerance to salinity 539 (Babu et al. 2017a). Several rice breeding programs across the globe have successfully adopted 540 this QTL for marker assisted breeding programs aimed at developing tolerant lines.

541 QTLs other than Saltol from Hasawi rice genotype have also been used for adoption into 542 breeding programs to derive rice inbred lines which led to the construction of a genetic map and 543 the identification of twenty new QTLs for salt tolerance (Bizimana et al. 2017). In addition to 544 rice, QTLs have also been analyzed for breeding salt tolerance in other crops. SSR markers have 545 been used to scan crop genomes to identify markers associated with salt tolerance in cotton 
546 (Zhao et al. 2016) and cucumber (Kere et al. 2017). In maize, Luo et al. (2017) mapped the

547 QTLs for salt tolerance using a doubled haploid population and high-density SNP markers. The 548 authors isolated major QTLs for salt tolerance and identified two candidate genes involved in ion 549 homeostasis. In soybean, Guan et al. (2014) used fine-mapping method in land races and wild 550 germplasm to isolate GmSALT3, a salt tolerance-associated gene. This gene was shown to be 551 localized to the endoplasmic reticulum and encoded a cation/ $\mathrm{H}^{+}$exchanger family transporter.

552 There has been steady progress in the information on crop genome sequence and accessibility to 553 genome datasets and this is expected to lead the molecular breeding of salt tolerance (Morton et 554 al. 2019). Crop breeding for salt tolerance can be primarily achieved through combining 555 mapping based genomic and phenotypic data, meta analysis of QTLs and detection of QTLs for 556 different tissue and stage specific tolerance traits. Extensive genome-wide diversity investigations need be conducted to explore allelic diversity at Saltol and other major traits of interest to guide marker assisted salt tolerance breeding (Ismail and Horie 2017).

\section{Alternative splicing and salt stress tolerance}

561 Multiple mature mRNAs may arise from one gene because of alternate splice site options. This 562 has been documented since long, but their role during stress tolerance was not known until 563 recently. A wide array of mature RNAs may arise due to intron retention, exon skipping, and 564 also alternative $5^{\prime}$ or $3^{\prime}$ splicing sites (Syed et al. 2012; Reddy et al. 2013). As pointed out by 565 Gracheva et al. (2011), alternatively spliced transcripts can yield proteins with different 566 structures or metabolic functions. Further, their cellular locations may also alter as demonstrated 567 by Kriechbaumer et al. (2012). Surprisingly, such alternatively spliced variants compete with 568 normal variants and therefore protein function interference has been noticed in a dominant 569 negative manner (Seo et al. 2011, Pose et al. 2013). Thus, alternative splicing can increase both transcriptome and proteome diversity.

A large body of emerging evidences suggest that there is a dynamic regulation of pre572 mRNA splicing which has been correlated with stress tolerance. A plethora of splicing factors 573 have been noticed in higher plants. Notably, in A. thaliana, Sm-like conserved protein 5 (LSm5) 574 has been recognized, which promotes inaccurate selection of splice sites in the genome of plants 575 (Cui et al. 2014). Another splicing factor PRP31 has been found later which is involved in transcriptional gene silencing and stress response in $A$. thaliana (Du et al. 2015). They reported 
577 that under cold stress, PRP31 is critical for pre-mRNA splicing. This splicing factor ensures 578 modulation of cold-responsive gene expression in A. thaliana. The experiments conducted by Du et al. (2015) infer that splicing machinery has a wide array of functions to perform such as premRNA splicing, gene regulation, transcriptional gene silencing and also abiotic stress response in higher plants. Thus, alternative splicing has been playing crucial roles at post-transcriptional level during abiotic stress tolerance. Another component of spliceosome called Ski-interacting protein (SKIP/SNW1) functions not only as a splicing factor but also as a transcriptional coactivator for induced genes (Chen et al. 2011; Wang et al. 2012; Feng et al. 2015). Interestingly, a DEAD box helicase has been found essential for pre-mRNA splicing, cold-responsive gene regulation, and cold tolerance in A. thaliana (Guan et al. 2013). Feng et al. (2015) found that SKIP controls alternative splicing under salt-stress environment by interfering with the cleavage of $5^{\prime}$ and $3^{\prime}$ splice donor and acceptor sites during stress conditions. How the mRNA splicing machinery modulates salt stress responses in plants has been answered only partially.

Not only salt stress, but also other stresses like temperature stress can produce splice variants. Alternative splicing has been found to incorporate premature termination codons (PTCs) into transcripts. Such transcripts are usually degraded, else produce truncated proteins in plants (Kalyna et al. 2012; Ottens and Gehring 2016). Dehydration responsive element-binding (DREB) protein 2B was found regulated under drought stress conditions by alternative splicing (Matsukura et al. 2010). One of the isoforms, OsDREB2B1, which retains an exon functions under normal conditions. The second isoform $O S D R E B 2 B 2$ produces a functional protein. This functional protein is triggered under both drought and high temperature stresses and also promotes the expression of several genes involved in stress tolerance (Matsukura et al. 2010). Further, Sugio et al. (2009), Staiger and Brown (2013), and Cheng et al. (2015), demonstrated that in Arabidopsis and rice the heat shock transcription factor A2 (HSFA2) helps the introduction of a PTC into the splicing isoform HSFA2-II and creates truncated protein under normal conditions. Contrarily, the alternative splice isoform HSFA2-I, instead encoded a protein 604 rice this splice isoform activated heat stress-responsive genes under high temperature conditions 605 (Cheng et al. 2015, Sugio et al. 2009). High temperature stress imposed in grapevines by Jiang et 606 al. (2017) resulted in the alternative splicing of $70 \%$ of the genes. Among the various splice 607 events, intron retention was frequent. Not surprisingly, intron retention events were high at 
608 higher temperatures $\left(40^{\circ} \mathrm{C}\right.$ and $\left.45^{\circ} \mathrm{C}\right)$ than at lower $\left(35^{\circ} \mathrm{C}\right)$, indicating that intron retention is a

609 key posttranscriptional regulation event. Simultaneously, the levels of RNA-binding proteins

610 were also increased with an increase in temperature. Their investigations revealed that a 611 multiprotein bridging factorlc and HSFA2 were associated with heat tolerance by modulating 612 alternative splicing and translational levels. The findings of $\mathrm{Gu}$ et al. (2018) highlighted the 613 critical role being played by another spliceosomal protein U1A which is involved in alternative 614 splicing as well as a regulatory role in hostile environments. Thus, alternative splicing, a 615 universal phenomenon appears to play many critical roles during abiotic stress conditions. 616 However, it is vital to find out the components that transduce the signal to splice the pre-mRNA 617 molecules and we need to improve our understanding on how these are involved in salt tolerance 618 or how they could be used to produce plants with improved tolerance and acceptable yields 619 under field conditions.

\section{Exploring halobiomes as a pool of genes for the production of salt-tolerant plants}

622 The halobiome can be referred to as a group of halophilic and/or halotolerant bacteria, algae, 623 fungi and plants (halophytes) that are able to withstand hypersaline environments. Hence, the 624 halobiome can be regarded as a potential reservoir of genes associated with salt-tolerance, which 625 could be used to engineer salt-tolerant crop plants. Salt-tolerance in halophytes involves 626 structural and developmental adaptations that include succulence, leaf shedding and the presence 627 of salt secreting assemblies such as salt glands or salt hairs (Shabala et al. 2014). Many 628 halophytes achieve tolerance using cellular mechanisms that include reduced $\mathrm{Na}^{+}$influx, 629 vacuolar compartmentalization of it or elimination of $\mathrm{Na}^{+}$ions through PM anti-porters (Flowers 630 and Colmer 2015). While all plants have cellular mechanisms that can potentially confer a 631 degree of salt-tolerance, in halophytes these mechanisms are expressed at higher levels than in 632 glycophytes.

633 Hence, quantitative not necessarily qualitative difference in the expression of key genes 634 or intrinsically more active proteins involved in salt tolerance is often the basis for better survival 635 in halophytes (Himabindu et al. 2016). Overexpression of salt tolerance genes such as SOS, $636 N H X, H K T$ etc., isolated from glycophytes or their halophytic gene homologs, showed that the 637 genes from halophytes generally provide a better salinity tolerance than those isolated from 638 glycophytes (Volkov 2015). Selection of effective promoters and regulatory sequences are the 
639 key to achieve good levels of transgene expression and recent studies show that the promoter 640 regions and the cis-regulatory elements of various stress-inducible genes found in halophytes are 641 strongly expressed under saline conditions. For example, promoter regions of the SIBADH and 642 SIPEAMT genes of Suaeda liaotungensis (Zhang et al. 2008; Li et al. 2016), the TsVPI from 643 Thellungiella halophila (Sun et al. 2010), and SbGSTU gene from Salicornia brachiata (Tiwari 644 et al. 2016) showed the ability to cause a multi-fold upregulation of their associated genes in 645 plants under salt stress. In addition, genes from halophytes including TFs (MYB, NAC, DREB) 646 associated with enzymatic or non-enzymatic antioxidants (BADH, APX, SOD etc.) and antiporter genes (NHX, HKT, SOS) were successfully used to enhance salt-tolerance in 648 glycophytic plants. Table 4 provides a summary of halophyte genes used in transgenesis649 experiments.

650 In general, halophytes are plants used for isolating genes implicated in salt tolerance, 651 however, some other salt tolerant non-plant organisms are also explored for this purpose. Genes 652 encoding enzymes involved in the production of some osmoprotectants, as well as antioxidative 653 enzymes and some ribosomal proteins from non-plant halobionts were successfully transferred 654 into plants, resulting in salt-tolerance (Table 5). Three genes, ectA (2,4-diaminobutyric acid 655 acetyltransferase), ectB (2,4-diaminobutyric acid aminotransferase) and ectC (L-ectoine 656 synthase), isolated from the halophilic bacterium Halomonas elongata, were expressed in 657 transgenic plants (Moghaieb et al. 2011). The resultant transgenic lines exhibited improved 658 ectoine synthesis and accumulation, and the plants grew better under saline conditions (100-300 $659 \mathrm{mM} \mathrm{NaCl}$ ) with improved biomass production and photosynthetic rates, and reduced lipid 660 peroxidation. Also, the genes encoding glycine sarcosine methyltransferase (GSMT) and 661 sarcosine dimethylglycine methyltransferase (SDMT), involved in the synthesis of glycine 662 betaine (GB), were isolated from the halotolerant cyanobacterium Aphanothece halophytica and 663 expressed in rice (Oryza sativa) plants (Niu et al. 2014). These rice transgenics accumulated high 664 levels of GB, and performed better under saline conditions in comparison with wild-type plants. 665 Ribosomal proteins from the extremely halophilic fungus Aspergillus glaucus were also shown 666 to alleviate salt stress when expressed in Arabidopsis thaliana and Nicotiana tabacum (Liu et al. 667 2014; Liang et al. 2015).

668 In addition to the successful application of transgenic technologies, the information 669 generated by whole genomes and transcriptome analysis of organisms from the halobiome could 
670 be of great value for crop improvement. The genomes of several halotolerant organisms were 671 sequenced including the halophytes like Thellungiella salsuginea (Wu et al. 2012), T. parvula 672 (Dassanayake et al. 2011), the halophilic methanogenic archaea Methanohalophilus mahii SLP ${ }^{\mathrm{T}}$ 673 (Spring et al. 2010), the halophilic archaeon Halococcus hamelinensis (Burns et al. 2012) and the 674 halophilic bacterium Halomonas elongate (Lafi et al. 2016), and these genomes could provide 675 candidate genes for future transformation studies in the future. However, it is important to note 676 that the transformation of crop plants using a single gene approach might not provide total 677 tolerance with high yield potential, as abiotic stress tolerance is often controlled by multiple genes (Abe et al. 2012). While omics and transgenic approaches were demonstrated to mitigate

679 the negative effects of salinity, introducing halotolerant bacterium into salt contaminated fields 680 was proved to be beneficial for the growth of Pisum sativum (Ali et al. 2015), Lycopersicon 681 esculentum (Fan et al. 2016), Arachis hypogaea (Sharma et al. 2016), Chenopodium quinoa 682 (Yang et al. 2016) and Triticum aestivum (Raheem and Ali 2015). Therefore, exploring 683 halobiomes to identify and isolate genes that confer salt-tolerance could be a promising approach 684 to enable crop plants to be grown in saline soils, but also simpler (but maybe more expensive and 685 laborious) agricultural methods like introduction of special soil bacteria and fungi may be also 686 interesting (Aroca and Ruiz-Lozano 2012; Shrivastava and Kumar 2015).

\section{$688 \quad 8$ Plant genome editing for producing salt-tolerant plants}

689 Genome editing (GE) methods have enabled specific and predictable modifications to be tailored 690 into crop genomes and these techniques are now revolutionizing plant breeding and crop 691 improvement efforts (Puchta 2017; van der Wiel et al. 2017). GE methods utilize customized 692 nucleases to introduce mutations (insertions or deletions) or precisely change gene sequences 693 (Jain, 2015). Several GE methods, e.g. zinc finger nucleases (ZFNs), transcriptional activator694 like effector nucleases (TALENS) and clustered regularly interspaced short palindromic repeat 695 (CRISPR)-Cas9 (CRISPR-associated nuclease 9) are now readily available (Voytas 2013; Kumar 696 and Jain 2015). These sequence-specific nucleases induce double-strand breaks (DSBs) in DNA 697 at specific sites in the genome which are subsequently followed by DNA repair processes (non698 homologous end joining or homology-directed repair) and result in genome modifications such 699 as targeted mutagenesis, gene insertion, or gene replacement. While the non-homologous end 
700 joining mode creates insertions or deletions, the homology-directed mode can achieve precise 701 modifications such as gene replacement or gene insertion.

702 The GE technology was successfully used on a variety of important crop plants (Puchta, 2017). 703 However, there have been few studies using GE to develop salt-tolerant plants. Due to the 704 complexity of the salt tolerance trait and the need to manipulate multiple genes, often in multiple 705 pathways, it is essential to introduce site-directed changes with no apparent off-target effects in 706 order to minimize unintended yield penalties (Osakabe et al. 2016; Shi et al. 2017). The ARGOS8 707 genomic sequence was edited using the CRISPR-Cas method and resultant maize lines exhibited 708 ubiquitous and higher levels of expression in most tissues and growth phases. The authors 709 suggested that this precise means of modifying specific genes and altering their expression could 710 be used to develop tolerant plants with high grain yields (Shi et al. 2017). Lou et al. (2017) 711 reported the generation of mutations in the gene for ABA signalling 'osmotic stress/ABA712 activated protein kinase 2' (SAPK2) to study its functional role, and observed that sapk2 mutants 713 exhibited an ABA-insensitive phenotype. Their study suggests that this gene could be useful to 714 improve salt and associated osmotic stress tolerance. GE can also be used to study the effects of 715 gene modifications on plant functionality and aid in designing plants with specific modifications 716 tailored to the trait of interest.

717 Genes associated with salt-tolerance could be specifically targeted using the CRISPR-Cas9 718 system as this approach was used to confer tolerance to other abiotic stresses as detailed below. 719 Osakabe et al. (2016) used truncated gRNAs (tru-gRNAs) and the CRISPR-Cas9 system for 720 accurate site-modification, while Merlot et al. (2007) induced mutation in an abiotic stress 721 tolerance gene encoding OST2 (AHA1) in Arabidopsis. Two dominant mutations in the ost2 722 locus resulted in the constitutive activity of guard cell proton pumps and inhibited stomatal 723 responses to ABA (Merlot et al. 2007). In addition, it was found that the use of tru-gRNA guided 724 Cas9, driven by a germline specific promoter, increased heritability in successive generations, 725 and the mutant plants exhibited altered stomatal response and hence this approach could be used 726 as a means to produce crops that can tolerate drought and/or salinity.

727 Salt-tolerance involves the controlled expression of multiple genes and the coordination of 728 regulatory, signalling and metabolic pathways. Moreover, functional redundancy among the 729 genetic pathways controlling salinity and other stress response pathways makes it difficult to 730 achieve total knockout of functionality. In this regard, it was advocated that multiplex genome 
731 editing (Zhou et al. 2014; Ma et al. 2015) can be employed to deduce the functions of multiple 732 functionally redundant genes involved in the same biological process, such as abiotic stress 733 responses (Jain 2015). To this end, multiple gRNAs could be used to accomplish the targeted 734 mutagenesis for traits like salt tolerance, homology-directed repair (HDR) may be an efficient 735 method to induce specific change(s) in salt responsive pathways. HDR-mediated gene targeting 736 can also be used for pyramiding of several genes involved in a stress response pathway or 737 regulatory network (Jain 2015). For multiplex gene editing in rice, Wang et al. (2018) developed 738 a simplified single transcriptional unit (SSTU) CRISPR system using FnCpf1, LbCpf1 or Cas9 to 739 target eight genes in the Late Embryogenesis Abundant (LEA) family, and generated a higher 740 proportion of heterozygous and chimeric mutants induced by $\mathrm{Cpf1}$ albeit with lower editing 741 efficiency. Though phenotypic nature of mutations has not been shown in this work, this study 742 can be helpful for multiplex genome editing in plants for stress tolerance.

743 It is now becoming evident through several reports of genome-wide association studies 744 that single base-pair changes constitute much of the variation in elite traits (Zhang et al. 2018). 745 This has formed a basis for base editing as a novel strategy for inducing point mutations in crops. 746 The recent advancement in the CRISPR/Cas9-mediated genome-editing is the base-editing 747 technology obviating the need for a DNA repair template (Komor et al. 2016). The methods use 748 different enzyme resource such as Cas9 nickase or dead Cas9 which can be conjoined with base749 converting enzymes (Hess et al. 2017). The cytosine (C) to uracil (U) conversion is mediated by 750 cytidine aminases, and this could result in $\mathrm{C} \cdot \mathrm{G}$ which could ultimately become $\mathrm{T} \bullet \mathrm{A}$ substitution 751 (Gaudelli et al. 2017). The $\mathrm{G} \bullet \mathrm{C}$ substitutions are created from the conversion of adenine (A) to 752 inosine (I) by adenine deaminases which is treated by polymerases as $\mathrm{G}$, and hence the $\mathrm{A} \bullet \mathrm{T}$ to $753 \mathrm{G} \bullet \mathrm{C}$ substitution. Presently the base editors for adenine and cytosine are reported to bring about 754 transition mutations of all the four bases in plants (Kang et al. 2018, Li et al. 2018a, Hua et al. 755 2019). The cytidine deaminase-based gene editing also has shown additional advantages of 756 inducing nonsense mutations to disorder and knockout gene functions (Billon et al. 2017). 757 Towards this, CRISPR/Cpfl system is a promising tool for gene editing especially AT-rich 758 regions (Begemann et al., 2017; Tang et al., 2017; Wang et al., 2017; Li et al., 2018b). The Cpf1 759 nucleases from Francisella novicida (FnCpf1) and Lachnospiraceae bacterium ND2006 760 (LbCpf1) have shown good potential for introducing accurate gene insertions and indel 761 mutations at the target site in the rice genome (Begemann et al. 2017). Both Cpfl produced up to 
$7628 \%$ high frequency of targeted insertions as compared to most often Cas 8 mediated genome 763 editing methods. With such an unprecedented arsenal of gene and base editing tools and 764 precision, plant gene engineering could undoubtedly lead to modifying genes involved in the 765 responses of plants to different stresses including production of salt-tolerant crop plants with 766 better yields.

\section{Conclusion and future outlook}

769 It is important to emphasize that studies investigating the TFs or other factors associated with 770 salinity stress should be carefully designed and evaluated in order not to describe and target less 771 relevant factors associated with the salt shock response (i.e. osmotic shock caused by exposure to 772 a single, high concentration of salt, which only occurs in nature due to rare climatic events such 773 as after a tsunami). Of greater importance are the salt-tolerance related processes that occur in 774 plants that are grown in fields where salt concentrations are gradually increasing over time 775 (Shavrukov 2013). The genes and TFs affected by salt shock versus gradual increases in field salt 776 levels may greatly vary and the latter seems to be agronomically relevant with respect to the 777 breeding of salt-tolerant crops. Similarly, breeding practices using selection for salt stress 778 tolerance at seedling stage (and under laboratory conditions) may be less relevant from the 779 agricultural point of view. Therefore, field trials using proper controls are needed to reliably 780 evaluate yields of different cultivars and thus to successfully improve crop productivity (Roy et 781 al. 2014).

782 Land plants have evolved many different salt-tolerance mechanisms and thus different plant 783 species have different transporters, gene expression patterns and mechanisms to regulate ion 784 fluxes. Unfortunately, our understanding of the ion transporters that are involved in the uptake, 785 exclusion, sequestration and transport of salt and thus salt-tolerance is still limited for most of the 786 crops. There are also many uncertainties, nomenclatural problems, contradictions based on 787 hastily made generalized statements, and yet unanswered questions with respect to salt-tolerance. 788 It appears that there are no general rules in salt tolerance mechanisms, or at least that salt789 tolerance mechanisms are likely to vary greatly from plant species to species (Nieves-Cordones 790 et al. 2016), cultivar to cultivar, population to population, and individual to individual, and 791 between organs, tissues and cells and also depending upon alternative splicing events. The 792 experimental and/or field treatments used and plant growth conditions can also have greater 
793 impact how plants respond to salt. Furthermore, it has to be considered that the same ion 794 transporter can have different effects on, for instance, shoot $\mathrm{Na}^{+}$accumulation when modified 795 (down- or upregulated) in different cell types (e.g. root epidermal cells vs. xylem cells) and 796 therefore the expression of ion transporter/transport components may need to be regulated at the 797 cell specific level (e.g. Møller et al. 2009). Also, minor differences in transcription or 798 protein/gene structure of a transporter can have great impact on a plant's ability to control ion 799 fluxes and thus tolerate salt stress (e.g. Cotsaftis et al. 2012). This outlines the need for further 800 functional analyses and characterization of various ion transporters from various organisms, an 801 improved understanding of their regulation and cell- or tissue-specific expression patterns, as 802 well as the need to characterize halobionts as potential sources of genes or TFs providing 803 improved salt tolerance in glycophytes (Volkov 2015; Assaha et al. 2017; Mishra and Tanna 804 2017). The real impact of such approach is demonstrated by the fact that alfalfa plants 805 overexpressing Salsola soda NHX gene could grow in up to $400 \mathrm{mM} \mathrm{NaCl}$ over 50 days (Li et al. 806 2011). Improved and enhanced ion sequestration in the vacuole under salt stress decreases the 807 solute potential of the cells and thus alleviates the osmotic component of salt stress by 808 facilitating the water uptake (Lv et al. 2008). Therefore, in spite of excellent promising studies 809 and the accumulation of an avalanche of information, engineering ion transport components for 810 improved salt tolerance is a complex and demanding task, especially if the aim is to develop crop 811 plants that are both salt-tolerant and possess agronomically important traits (i.e. yield) when 812 grown under commercially relevant field conditions. This is not an easy task even with newest 813 genetic engineering tools or using transcription factors, because alterations in ion homeostasis 814 often result in yield burden. Not surprisingly, to the best of our knowledge, no GM crops with 815 increased salinity tolerance have been commercialized (Fita et al. 2015). Our recent searches in 816 major relevant public databases (USDA APHIS - https:// www. aphis. usda.gov / aphis / ourfocus 817 /biotechnology/ permits- notifications- petitions; ISAAA - http:// www.isaaa.org /gm approval 818 database/) resulted in no records for 'salt stress' in ISAAA and a few records in APHIS which 819 requested permission for field trials of some potentially salt tolerant GM crops (e.g. soybean, 820 Chinese silvergrass), but no data on potentially commercialized and cultivated salt tolerant GM 821 crops have been found. However, certain field-based studies where overexpression of gene(s) has 822 improved the salinity tolerance and growth performance of transgenic plants in saline fields 823 (Paspula et al. 2011; Schilling et al. 2014) should be looked upon as lead for developing salt- 
824 tolerant crops at commercial levels. In addition to a combination of genetic engineering and 825 conventional breeding tools, other practices like for instance the domestication or increased use 826 of halophyte plants (e.g. quinoa) as crops on saline soils (Fita et al. 2015) look promising.

\section{Acknowledgements}

KS acknowledges the Bolyai János Research Scholarship of the H.A.S. and the National Research Development and Innovation Office of Hungary (Grant OTKA FK 124748) for support. SHW thanks University Grant Commission, New Delhi, India for providing a Raman 833 Fellowship for post-doctoral research at Michigan State University, East Lansing, USA. VK 834 acknowledges the financial support from Science and Engineering Research Board, Government of India (EMR/2016/003896). RG is grateful to the CSIR for providing financial assistance. PBK 836 is thankful for the CSIR-Emeritus Scientist Fellowship through the Grant No. 38(1325)/12/EMR837 II) from CSIR, New Delhi.

\section{Conflict of Interest}

840 Authors declare that there is no conflict of interest

\section{References}

Abe A, Kosugi S, Yoshida K, Natsume S, Takagi H, Kanzaki H, Innan H (2012) Genome sequencing reveals agronomically important loci in rice using MutMap. Nat Biotechnol, 30:174-178.

Abdelkader AF, Aronsson H, Solymosi K, Böddi B, Sundqvist C (2007) High salt stress induces swollen prothylakoids in dark-grown wheat and alters both prolamellar body conversion and reformation after irradiation. J Exp Bot 58:2553-2564.

Aghaee-Bakhtiari SH, Arefian E, Lau P (2018) miRandb: a resource of online services for miRNA research. Brief Bioinformatics 19:254-262.

Akram S, Siddiqui MN, Hussain BN, Al Bari MA, Mostofa MG, Hossain MA, Tran LSP (2017) Exogenous glutathione modulates salinity tolerance of soybean [Glycine max (L.) Merrill] at reproductive stage. J Plant Growth Regul 36:877-888. 
Alexandersson E, Saalbach G, Larsson C, Kjellbom P (2004) Arabidopsis plasma membrane proteomics identifies components of transport, signal transduction and membrane trafficking. Plant Cell Physiol 45:1543-1556.

Ali Z, Ullah N, Naseem S, Haq MI, Jacobsen HJ (2015) Soil bacteria conferred a positive relationship and improved salt stress tolerance in transgenic pea (Pisum sativum L.) harboring $\mathrm{Na}^{+} / \mathrm{H}^{+}$antiporter. Turkish J Bot 39:962-72.

Almeida DM, Oliveira MM, Saibo NJM (2017) Regulation of $\mathrm{Na}^{+}$and $\mathrm{K}^{+}$homeostasis in plants: towards improved salt stress tolerance in crop plants. Genet Mol Biol 40:326-345.

Amtmann A, Beilby MJ (2010) The role of ion channels in plant salt tolerance, in: Demidchik, V., Maathuis, F. (Eds.), Ion Channels and Plant Stress Responses, Signaling and Communication in Plants. Springer-Verlag, Berlin Heidelberg, pp. 23-46.

An J, Lai J, Sajjanhar A, Lehman ML, Nelson CC (2014) miRPlant: an integrated tool for identification of plant miRNA from RNA sequencing data. BMC Bioinformatics 15:275.

An X, Chen J, Zhang J, Liao Y, Dai L, Wang B, Peng D (2015) Transcriptome profiling and identification of transcription factors in ramie (Boehmeria nivea L. Gaud) in response to PEG treatment, using illumina paired-end sequencing technology. Int J Mol Sci 16:34933511.

Anjaneyulua E, Reddy PS, Sunita MSL, Kavi Kishor PB, Meriga B (2014) Salt tolerance and activity of antioxidative enzymes of transgenic finger millet overexpressing a vacuolar $\mathrm{H}^{+}$-pyrophosphatase gene (SbVPPase) from Sorghum bicolor. J Plant Physiol 171:789798.

Apse MP, Aharon GS, Snedden WA, Blumwald E (1999). Salt tolerance conferred by overexpression of a vacuolar $\mathrm{Na}^{+} / \mathrm{H}^{+}$antiport in Arabidopsis. Science 285: 1256-1258. Doi:10.1126/science.285.5431.1256.

Apse MP, Blumwald E (2007) $\mathrm{Na}^{+}$transport in plants. FEBS Lett 581:2247-2254.

Ardie S, Liu S, Takano T (2010) Expression of the AKT1-type $\mathrm{K}^{+}$channel gene from Puccinellia tenuiflora, PutAKT1, enhances salt tolerance in Arabidopsis. Plant Cell Rep 29:865-874.

Aroca P, Ruiz-Lozano J (2012) Salinity stress alleviation using arbuscular mycorrhizal fungi. A review. Agron Sustain Dev 32:181-200. 
Assaha DVM, Ueda A, Saneoka H, Al-Yahyai R, Yaish MW (2017) The role of Na+ and K+ transporters in salt stress adaptation in glycophytes. Front Physiol 8:509.

Asif MA, Zafar Y, Iqbal J, Iqbal MM, Rashid U, Ali GM, Nazir F (2011) Enhanced expression of AtNHX1, in transgenic groundnut (Arachis hypogaea L.) improves salt and drought tolerance. Mol Biotechnol 49:250-256.

Baisakh N, Ramana Rao MV, Rajasekaran K, Subudhi P, Janda J, Galbraith D, Pereira A (2012) Enhanced salt stress tolerance of rice plants expressing a vacuolar $\mathrm{H}^{+}$-ATPase subunit $\mathrm{cl}$ (SaVHAc1) gene from the halophyte grass Spartina alterniflora Löisel. Plant Biotechnol J 10:453-64.

Babu NN, Krishnan SG, Vinod KK, Krishnamurthy SL, Singh VK, Singh MP, Singh R, Ellur RK, Rai V, Bollinedi H, Bhowmick PK, Yadav AK, Nagarajan M, Singh NK, Prabhu KV, Singh AK (2017) Marker aided incorporation of Saltol, a major QTL associated with seedling stage salt tolerance into Oryza sativa 'Pusa Basmati 1121'. Front Plant Sci 8:41

Baisakh N, Subudhi P, Varadwaj P (2008) Primary responses to salt stress in a halophyte Spartina alterniflora (Loisel). Funct Integ Genom 8:287-300.

Bao AK, Du BQ, Touil L, Kang P, Wang QL, Wang SM (2016) Co-expression of tonoplast cation $/ \mathrm{H}^{+}$antiporter and $\mathrm{H}^{+}$-pyrophosphatase from xerophyte Zygophyllum xanthoxylum improves alfalfa plant growth under salinity, drought and field conditions. Plant Biotechnol J 14:964-975.

Bao AK, Wang YW, Xi JJ, Liu C, Zhang JL. Wang SM (2014) Co-expression of xerophyte Zygophyllum xanthoxylum ZxNHX and ZxVP1-1 enhances salt and drought tolerance in transgenic Lotus corniculatus by increasing cations accumulation. Funct Plant Biol 41:203-214.

Baras AS, Mitchell CJ, Myers JR, Gupta S, Weng LC, et al. (2015) miRge - A multiplexed method of processing small RNA-seq data to determine microRNA entropy. PLoS ONE 10:e0143066. doi:10.1371/journal.pone.0143066

Barragan V, Leidi EO, Andres Z, Rubio L, Luca AD, Fernandez JA, Cubero B, Pardo JM (2012) Ion exchangers NHX1 and NHX2 mediate active potassium uptake into vacuoles to regulate cell turgor and stomatal function in Arabidopsis. Plant Cell 24:1127-1142

Bassil E, Blumwald E (2014) The ins and outs of intracellular ion homeostasis: NHX-type cation/ $\mathrm{H}^{+}$transporters. Curr Opin Plant Biol 22:1-6 
916 Bassil E, Ohto MA, Esumi T, Tajima H, Zhu Z, Cagnac O, Belmonte M, Peleg Z, Yamaguchi T, 917 Blumwald E (2011a) The Arabidopsis intracellular $\mathrm{Na}^{+} / \mathrm{H}^{+}$antiporters NHX5 and NHX6 918 are endosome associated and necessary for plant growth and development. Plant Cell 23:224-239

Bassil E, Tajima H, Liang YC, Ohto MA, Ushijima K, Nakano R, Esumi T, Coku A, Belmonte M, Blumwald E (2011b) The Arabidopsis $\mathrm{Na}^{+} / \mathrm{H}^{+}$antiporters NHX1 and NHX2 control vacuolar $\mathrm{pH}$ and $\mathrm{K}^{+}$homeostasis to regulate growth, flower development, and reproduction. Plant Cell 23:3482-3492

Bayat F, Shiran B, Belyaevc DV (2011) Overexpression of HvNHX2, a vacuolar $\mathrm{Na}^{+} / \mathrm{H}^{+}$ antiporter gene from barley, improves salt tolerance in Arabidopsis thaliana. Aust J Crop Sci 5:428-432

Billon P, Bryant EE, Joseph SA, Nambiar TS, Hayward SB, Rothstein R, Ciccia A. (2017).

Begemann MB, Gray BN, January E, Gordon GC, He Y, Liu H, Wu X, Brutnell TP, Mockler TC, Oufattole M. (2017) Precise insertion and guided editing of higher plant genomes using Cpf1 CRISPR nucleases. Sci Rep 7(1):11606

Bhaskaran S, Savithramma DL (2011) Co-expression of Pennisetum glaucum vacuolar $\mathrm{Na}^{+} / \mathrm{H}^{+}$ antiporter and Arabidopsis $\mathrm{H}^{+}$-pyrophosphatase enhances salt tolerance in transgenic tomato. J Exp Bot 62:5561-5570

Bose J, Munns R, Shabala S, Gilliham M, Pogson B, Tyerman SD (2017) Chloroplast function

and ion regulation in plants growing on saline soils: lessons from halophytes. J Exp Bot 68:3129-3143. Induction of STOP Codons. Mol Cell 67(6):1068-1079

Bizimana JB, Luzi-kihupi A, Murori RW, Singh RK (2017) Identification of quantitative trait loci for salinity tolerance in rice (Oryza sativa L.) using IR29/Hasawi mapping population. J Genet 96(4):571-582

Blumwald E, Aharon GS, Apse MP (2000) Sodium transport in plant cells. Biochim Biophys Acta 1465:140-151.

- Acta 1465:140-151.

Bose J, Rodrigo-Moreno A, Lai D, Xie Y, Shen W, Shabala S (2015) Rapid regulation of the plasma membrane $\mathrm{H}^{+}$-ATPase activity is essential to salinity tolerance in two halophyte species, Atriplex lentiformis and Chenopodium quinoa. Ann Bot 115:481-494. 
Brini F, Hanin M, Lumbreras V, Amara I, Khoudi H, Hassairi A, Masmoudi K (2007) Overexpression of wheat dehydrin DHN-5 enhances tolerance to salt and osmotic stress in Arabidopsis thaliana. Plant Cell Rep 26:2017-2026.

Bunney TD, van den Wijngaard PW, de Boer AH (2002) 14-3-3 protein regulation of proton pumps and ion channels. Plant Mol Biol 50:1041-1051.

Burns BP, Gudhka RK, Neilan BA (2012) Genome sequence of the halophilic archaeon Halococcus hamelinensis. J Bacteriol 194:2100-2101.

954 Cabello JV, Lodeyro AF, Zurbriggen MD (2014) Novel perspectives for the engineering of abiotic stress tolerance in plants. Curr Opin Biotechnol 26:62-70.

Campbell MT, Bandillo N, Al Shiblawi FRA, Sharma S, Liu K et al. (2017) Allelic variants of OsHKT1;1 underlie the divergence between indica and japonica subspecies of rice (Oryza sativa) for root sodium content. PLoS Genet 13:e1006823. https://doi.org/10.1371/journal. pgen.1006823.

Campos JF, Cara B, Pérez-Martín F, Pineda B, Egea I, Flores FB, Lozano R (2016) The tomato mutant ars1 (altered response to salt stress 1) identifies an R1-type MYB transcription factor involved in stomatal closure under salt acclimation. Plant Biotechnol J 14:13451356.

Cao D, Li Y, Liu B, Kong F, Tran LSP (2018) Adaptive mechanisms of soybean grown on saltaffected soils. Land Degrad Devel 29:1054-64.

Cao Y, Jin X, Huang H, Derebe MG, Levin EJ et al. (2011) Crystal structure of a potassium ion transporter, TrkH. Nature 471:336-340. doi: 10.1038/nature09731.

Carraretto L, Teardo E, Checchetto V, Finazzi G, Uozumi N, Szabo I (2016) Ion channels in plant bioenergetic organelles, chloroplasts and mitochondria: from molecular identification to function. Mol Plant 93:71-395.

Chang WJ, Xiwen L, Jiahong Z, Wei F, Zhili Z (2015) An aquaporin gene from halophyte Sesuvium portulacastrum, SpAQP1, increases salt tolerance in transgenic tobacco. Plant Cell Rep 35:385-395.

Chaves I, Costa BV, Rodrigues AS, Bohn A, Miguel CM (2017) miRPursuit-a pipeline for automated analyses of small RNAs in model and nonmodel plants. FEBS Lett 591:22612268. 
977 Cheeseman JM (2015) The evolution of halophytes, glycophytes and crops, and its implications 978 for food security under saline conditions. New Phytol 206:557-570.

979 Chen GH, Yan W, Yang LF, Gai JY, Zhu YL (2014) Overexpression of StNHX1, a novel 980 vacuolar $\mathrm{Na}^{+} / \mathrm{H}^{+}$antiporter gene from Solanum torvum, enhances salt tolerance in transgenic vegetable soybean. Hort Environ Biotechnol 55:213-221.

982 Chen Y, Lanlan L, Junqin Z, Jingbo C, Hailin G, Aigui G, Jianxiu L (2015) Heterologous 983 expression of the halophyte Zoysia matrella $\mathrm{H}^{+}$-pyrophosphatase gene improved salt tolerance in Arabidopsis thaliana. Plant Physiol Biochem 91:49-55.

Chen Y, Zhang L, Jones KA (2011). SKIP counteracts p53-mediated apoptosis via selective regulation of p21Cip1 mRNA splicing. Genes Develop 25: 701-716.

Cheng Q, Zhou Y, Liu Z, Zhang L, Song G, Guo Z, Wang W, et al. (2015). An alternatively spliced heat shock transcription factor, OsHSFA2dI, functions in the heat stress-induced unfolded protein response in rice. Plant Biol. 17: 419-429.

Cotsaftis O, Plett D, Shirley N, Tester M, Hrmova M (2012) A two-staged model of $\mathrm{Na}^{+}$ exclusion in rice explained by $3 \mathrm{D}$ modeling of HKT transporters and alternative splicing. PLoS ONE 7:e39865.

Cobb JN, Biswas PS, Platten JD (2019) Back to the future: revisiting MAS as a tool for modern plant breeding. Theor Appl Genet 132: 647

Counillon L, Pouyssegur J (2000) The expanding family of eukaryotic $\mathrm{Na}^{+} / \mathrm{H}^{+}$exchangers. J Biol Chem 275:1-4.

Cui P, Zhang S, Ding F, Ali S, Xiong L (2014). Dynamic regulation of genome-wide pre-mRNA splicing and stress tolerance by the Sm-like proteins LSm5 in Arabidopsis. Genome Biol 15: R1.

Dassanayake M, Oh DH, Haas JS, Hernandez A, Hong H, Ali S, Cheeseman JM (2011) The genome of the extremophile crucifer Thellungiella parvula. Nat Genet 43:913-918.

Demidchik V, Maathuis FJM (2007) Physiological roles of nonselective cation channels in plants: from salt stress to signalling and development. New Phytol 175:387-404.

1005 
Dong QL, Liu DD, Wang QJ, Fang MJ, Hao YJ, Yao YX (2015) Ectopic expression of subunit $A$ of vacuolar $\mathrm{H}^{+}$-ATPase from apple enhances salt tolerance in tobacco plants. Russ J Plant Physiol 62:847-855.

Du JL, Zhang SW, Huang HW, Cai T, Li L, Chen S, He XJ (2015). The splicing factor PRP31 is involved in transcriptional gene silencing and stress response in Arabidopsis. Mol Plant 8: 1053-1068.

Evers M, Huttner M, Dueck A, Meister G, Engelmann JC (2015) miRA: adaptable novel miRNA identification in plants using small RNA sequencing data. BMC Bioinformatics 16:370.

Fahlgren N, Hill ST, Carrington JC, Carbonell A (2016) P-SAMS: a web site for plant artificial microRNA and synthetic trans-acting small interfering RNA design. Bioinformatics 32:157-158.

Fan P, Chen D, He Y, Zhou Q, Tian Y, Gao L (2016) Alleviating salt stress in tomato seedlings using Arthrobacter and Bacillus megaterium isolated from the rhizosphere of wild plants grown on saline-alkaline lands. Int J Phytoremed 18:1113-1121.

FAO (2015) FAO Land and Plant Nutrition Management Service. Rome: Food and Agriculture Organization of the United Nations.

Feng J, Li J, Gao Z, Lu Y, Yu J, Zheng Q, Yan S, Zhang W, He H, Ma L, Zhu Z (2015). SKIP confers osmotic tolerance during salt stress by controlling alternative gene splicing in Arabidopsis. Mol Plant 8: 1038-1052.

Fita A, Rodríguez-Burruezo A, Boscaiu M, Prohens J and Vicente O (2015) Breeding and domesticating crops adapted to drought and salinity: A new paradigm for increasing food production. Front Plant Sci 6:978.

1034 Fuchs I, Stölzle S, Ivashikina N, Hedrich R (2005) Rice $\mathrm{K}^{+}$uptake channel OsAKT1 is sensitive 1035 to salt stress. Planta 221:12-221. 
1036 Fuglsang AT, Paez-Valencia J, Gaxiola RA (2010) Plant proton pumps: Regulatory circuits involving $\mathrm{H}^{+}$-ATPase and $\mathrm{H}^{+}$-PPase. In: Geisler M, Venema $\mathrm{K}$ (eds). Transporters and Pumps in Plant Signaling, Springer, Berlin pp 39-64.

Furumoto T, Yamaguchi T, Ohshima-Ichie Y, Nakamura M, Tsuchida-Iwata Y, et al. (2011) A plastidial sodium-dependent pyruvate transporter. Nature 476:472-475.

Gaudelli NM, Komor AC, Rees HA, Packer MS, Badran AH, Bryson DI, Liu DR (2017).

1045 Programmable base editing of $\mathrm{A} \bullet \mathrm{T}$ to $\mathrm{G} \bullet \mathrm{C}$ in genomic DNA without DNA cleavage. Nature. $1046 \quad 551: 464-71$.

1047 Gaxiola RA, Li J, Undurraga S, Dang LM, Allen GJ, Alper SL, Fink GR (2001) Drought and 1048 salt-tolerant plants result from overexpression of the AVP1 $\mathrm{H}^{+}$-pump. Proc Natl Acad Sci 1049 USA, 98:11444-11449.

1050 Gaxiola RA, Palmgren MG, Schumacher K (2007) Plant proton pumps. FEBS Lett 581:220410512214.

1052 Gevaudant F, Duby G, Stedingk EE, Zhao R, Morsomme P, Boutry M (2007) Expression of a 1053 constitutively activated plasma membrane $\mathrm{H}^{+}$-ATPase alters plant development and increases salt tolerance. Plant Physiol 144:1763-1776.

1055 Golldack D, Deitz KJ (2000) Salt-induced expression of the vacuolar $\mathrm{H}^{+}$-ATPase in the common ice plant is developmentally controlled and tissue specific. Plant Physiol 125:1643-1654.

1057 Golldack D, Quigley F, Michalowski CB, Kamasani UR, Bohnert HJ (2003) Salinity stress1058 tolerant and -sensitive rice (Oryza sativa L.) regulate AKT1-type potassium channel 1059 transcripts differently. Plant Mol Biol 51:71-81.

1060 Gouiaa S, Khoudi $\mathrm{H}$ (2015) Co-expression of vacuolar $\mathrm{Na}^{+} / \mathrm{H}^{+}$antiporter and $\mathrm{H}^{+}-$ 1061 pyrophosphatase with an IRES-mediated dicistronic vector improves salinity tolerance 1062 1063 and enhances potassium biofortification of tomato. Phytochemistry 117:537-546.

1064 Weissman JS, et al. (2011). Ganglion-specific splicing of TRPV1 underlies infrared 1065 sensation in vampire bats. Nature 476: 88-91. 
1066 Gu J, Xia Z, Luo Y, Jiang X, Qian B, Xie H, Zhu JK, Xiong L, Zhu J, Wang ZY (2018).

1067 Spliceosomal protein U1A is involved in alternative splicing and salt stress tolerance in 1068 Arabidopsis thaliana. Nucl Acid Res. 46: 1777-1792.

1069 Guan B, Hu YZ, Zeng YL, Wang Y, Zhang FC (2011) Molecular characterization and functional 1070 analysis of a vacuolar $\mathrm{Na}^{+} / \mathrm{H}^{+}$antiporter gene ( $\mathrm{HcNHX1)}$ from Halostachys caspica. Mol Biol Rep 38:1889-1899.

Guo S, Yin H, Zhang X, Zhao F, Li P, Chen S, Zhang H (2006) Molecular cloning and

Guan R, Qu Y, Guo Y, Yu L, Liu Y, et al. 2014. Salinity tolerance in soybean is modulated by natural variation in GmSALT3. Plant J. 80:937-50

Guan Q, Wu J, Zhang Y, Jiang C, Liu R, Chai C, Zhu J (2013). A DEAD box RNA helicase is critical for pre-mRNA splicing, cold-responsive gene regulation and cold tolerance in Arabidopsis. Plant Cell 25: 342-356. characterization of a vacuolar $\mathrm{H}^{+}$-pyrophosphatase gene, $S s V P$, from the halophyte Suaeda salsa and its overexpression increases salt and drought tolerance of Arabidopsis. Plant Mol Biol 60:41-50.

Gupta B, Huang B (2014) Mechanism of salinity tolerance in plants: physiological, biochemical, and molecular characterization. Int J Genom 2014:701596.

Gurjar AKS, Panwar AS, Gupta R, Mantri SS (2016) PmiRExAt: plant miRNA expression atlas database and web applications. Database 2016: baw060. doi:10.1093/database/baw060.

Hamamoto S, Horie T, Hauser F, Deinlein U, Schroeder JI, Uozumi N (2015) HKT transporters mediate salt stress resistance in plants: from structure and function to the field. Curr Opin Biotechnol 32:113-120.

Han N, Wenjun L, Xi H, Qun S, Baoshan W, Xinjie Z (2011) Expression of a Suaeda salsa vacuolar $\mathrm{H}^{+} / \mathrm{Ca}^{2+}$ transporter gene in Arabidopsis contributes to physiological changes in salinity. Plant Mol Biol Rep 30:470-477.

Hasegawa PM (2013) Sodium $\left(\mathrm{Na}^{+}\right)$homeostasis and salt tolerance of plants. Environ Exp Bot 92:19-31.

1093 He XL, Huang X, Shen YZ, Huang ZJ (2014) Wheat V-H -ATPase subunit genes significantly 1094 affect salt tolerance in Arabidopsis thaliana. PLoS One 9:e86982.

1095 Hess GT, Tycko J, Yao D, Bassik MC (2017). Methods and Applications of CRISPR-Mediated 1096 Base Editing in Eukaryotic Genomes. Mol Cell 68(1): 26-43 
Himabindu Y, Chakradhar T, Reddy MC, Kanygin A, Redding KE, Chandrasekhar T (2016) Salt-tolerant genes from halophytes are potential key players of salt tolerance in glycophytes. Environ Exp Bot 124:39-63.

Horie T, Sugawara M, Okada T, Taira K, Kaothien-Nakayama P, et al. (2011) Rice sodiuminsensitive potassium transporter, OsHAK5, confers increased salt tolerance in tobacco BY2 cells. J Biosci Bioeng 111:346-356.

Hu YZ, Zeng YL, Guan B, Zhang FC (2012) Overexpression of a vacuolar $\mathrm{H}^{+}$-pyrophosphatase and a B subunit of $\mathrm{H}^{+}$-ATPase cloned from the halophyte Halostachys caspica improves salt tolerance in Arabidopsis thaliana. Plant Cell Tiss Org Cult 108:63-71.

Hua K, Tao X, Zhu JK (2019) Expanding the base editing scope in rice by using Cas9 variants. Plant Biotechnol J 17(2): 499-504.

Huang Q, Wang Y, Li B, Chang J, Chen M, Li K, He G (2015) TaNAC29, a NAC transcription factor from wheat, enhances salt and drought tolerance in transgenic Arabidopsis. BMC Plant Biol 15:268.

Huertas R, Rubio L, Cagnac O, Garcia-Sanchez MJ, Alche JDD, et al. (2013) $\mathrm{The} \mathrm{K}^{+} / \mathrm{H}^{+}$ antiporter LeNHX2 increases salt tolerance by improving $\mathrm{K}^{+}$homeostasis in transgenic tomato. Plant Cell Environ 36:2135-2149.

Ismail AM, Horie T (2017) Genomics, Physiology, and Molecular Breeding Approaches for Improving Salt Tolerance. Annu Rev Plant Biol. 68:405-434

Jacobs A, Ford K, Kretschmer J, Tester M (2011) Rice plants expressing the moss sodium pumping ATPase PpENA1 maintain greater biomass production under salt stress. Plant Biotechnol J 9:838-847.

Jain M (2015) Functional genomics of abiotic stress tolerance in plants: a CRISPR approach. Front Plant Sci 6:375.

James RA, Blake C, Byrt CS, Munns R (2011) Major genes for $\mathrm{Na}^{+}$exclusion, Nax1 and $\mathrm{Nax} 2$ (wheat $H K T 1 ; 4$ and $H K T 1 ; 5$ ), decrease $\mathrm{Na}^{+}$accumulation in bread wheat leaves under saline and waterlogged conditions. J Exp Bot 62:2939-2947.

Jha B, Mishra A, Jha A, Joshi M (2013) Developing transgenic Jatropha using the SbNHX1 gene from an extreme halophyte for cultivation in saline wasteland. PLoS One 8:e71136.

Ji H, Pardo JM, Batelli G, Van Oosten MJ, Bressan RA, Li X (2013) The salt overly sensitive (SOS) pathway: Established and emerging roles. Mol Plant 6:275-286. 
1128 Jia GX, Zhu ZQ, Chang FQ, Li YX (2002) Transformation of tomato with the BADH gene 1129 from Atriplex improves salt tolerance. Plant Cell Rep 21:141-146.

1130 Jiang J, Liu X, Liu C, Liu G, Li S, Wang L (2017). Integrating omics and alternative splicing 1131 reveals insights into grape response to high temperature. Plant Physiol. 173: 1502-1518.

1132 Jiang X, Leidi EO, Pardo JM (2010) How do vacuolar NHX exchangers function in plant salt 1133 tolerance? Plant Signal Behav 55:792-795.

1134 Jin X, Xue Y, Wang R, Xu R, Bian L, Zhu B, Yao Q (2013) Transcription factor OsAP21 gene 1135 increases salt/drought tolerance in transgenic Arabidopsis thaliana. Mol Biol Rep 1136 40:1743-1752.

1137 Joshi R, Wani SH, Singh B, Bohra A, Dar ZA, Lone AA, Singla-Pareek SL (2016) Transcription factors and plants response to drought stress: current understanding and future directions. Front Plant Sci 7:1029.

Kalyna M, Simpson CG, Syed NH, Lewandowska D, Marquez Y, Kusenda B, Marshall J. et al. (2012). Alternative splicing and nonsense mediated decay modulate expression of important regulatory genes in Arabidopsis. Nucl Acids Res 40: 2454-2469.

1147 Kere GM, Chen C, Guo Q, Chen J (2017) Genetics of salt tolerance in cucumber (Cucumis sativus L.) revealed by quantitative traits loci analysis. Sci Lett 5(1):22-30

Khare T, Shriram V, Kumar V (2018) RNAi Technology: The role in development of abiotic stress-tolerant crops. In Wani SH (ed) Biochemical, Physiological and Molecular Avenues for Combating Abiotic Stress Tolerance in Plants, Elsevier, pp. 117-133

1152 Khare, T., Kumar, V. \& Kavi Kishor, PB (2015). $\mathrm{Na}^{+}$and $\mathrm{Cl}^{-}$ions show additive effects under $\mathrm{NaCl}$ stress on induction of oxidative stress and the responsive antioxidative defense in rice. Protoplasma, 252, 1149-1165.

1155 Khoudi H, Nouri-Khemakhem A, Gouiaa S, Masmoudi K (2009) Optimization of regeneration 1156 and transformation parameters in tomato and improvement of its salinity and drought 1157 tolerance. Afr J Biotechnol 8:6068-6076. 
1158 Kirsch M, An Z, Viereck R, Low R, Rausch T (1996) Salt stress induces an increased expression of V-type $\mathrm{H}^{+}$-ATPase in mature sugar beet leaves. Plant Mol Biol 32:543-547.

1160 Kluge C, Lamkemeyer P, Tavakoli N, Golldack D, Kandlbinder A, Dietz KJ (2003) cDNA cloning of 12 subunits of the V-type ATPase from Mesembryanthemum crystallinum and their expression under stress. Mol Membrane Biol 20:171-183.

Klychnikov OI, Li KW, Lill H, de Boer AH (2007) The V-ATPase from etiolated barley (Hordeum vulgare L.) shoots is activated by blue light and interacts with 14-3-3 proteins. J Exp Bot 58:1013-123.

Kobayashi S, Abe N, Yoshida KT, Liu S, Takano T (2012) Molecular cloning and characterization of plasma membrane- and vacuolar-type $\mathrm{Na}^{+} / \mathrm{H}^{+}$antiporters of an alkaline-salt-tolerant monocot, Puccinella tenuiflora. J Plant Res 125:587-594.

Komor AC, Kim YB, Packer MS, Zuris JA, Liu DR. (2016) Programmable editing of a target base in genomic DNA without double-stranded DNA cleavage. Nature 533:420-4.

Kozomara A, Griffiths-Jones S (2014) miRBase: annotating high confidence microRNAs using deep sequencing data. Nucl Acids Res 42:D68-D73.

Kriechbaumer V, Wang P, Hawes C, Abell BM (2012). Alternative splicing of the auxin biosynthesis gene YUCCA4 determines its subcellular compartmentation. Plant J 70: 292-302.

Kumar V, Jain M (2015) The CRISPR-Cas system for plant genome editing: advances and opportunities. J Exp Bot 66:47-57.

Kronzucker HJ, Britto DT (2011) Sodium transport in plants: a critical review. New Phytol 189:54-81.

Kumar T, Khan MR, Jan SA, Ahmad N, Ali NN, et al. (2014). Efficient regeneration and genetic transformation of sugarcane with AVP1 gene. Am Eurasian J Agri Environ Sci 14:165171.

Kumar V, Khare T (2016) Differential growth and yield responses of salt-tolerant and susceptible rice cultivars to individual $\left(\mathrm{Na}^{+}\right.$and $\left.\mathrm{Cl}^{-}\right)$and additive stress effects of $\mathrm{NaCl}$. Acta Physiol Plant 38:1-9. doi: 10.1007/s11738-016-2191-x

Kumar V, Khare T, Sharma M, Wani SH (2017a) ROS-induced signaling and gene expression in crops under salinity stress. In; Khan M, Khan N (eds), Springer, Singapore pp.159184. 
1189 Kumar V, Khare T, Shriram V, Wani SH (2017b) Plant small RNAs: the essential epigenetic regulators of gene expression for salinity stress responses and tolerance. Plant Cell Rep 37:61-75.

Kumar A, Kumar A, Kumar P, Lata C, Kumar S (2018) Effect of individual and interactive alkalinity and salinity on physiological, biochemical and nutritional traits of marvel grass. Ind J Exp Biol 56:573-581

Kumari PH, Kumar SA, Katam R, Reddy PS, Nagaraju M, et al. (2018) Genome-wide identification and analysis of Arabidopsis sodium proton antiporter (NHX) and human sodium proton exchanger (NHE) homologs in Sorghum bicolor. Genes 9:236. doi:10.3390/genes9050236.

Kumari PH, Kumar SA, Sivan P, Katam R, Suravajhala P, Rao KS, Varshney, RK, Kavi Kishor PB (2017) Overexpression of a plasma membrane bound $\mathrm{Na}^{+} / \mathrm{H}^{+}$antiporter-like protein $(S b N H X L P)$ confers salt tolerance and improves fruit yield in tomato by maintaining ion homeostasis. Front Plant Sci 7:2027. doi: 10.3389/fpls.2016.02027.

Lafi FF, Ramirez-Prado JS, Alam I, Bajic VB, Hirt H, Saad MM (2016) Draft genome sequence of Halomonas elongata strain $\mathrm{K} 4$, an endophytic growth-promoting bacterium enhancing salinity tolerance in planta. Genome Announcements 4:e01214-16.

Latef AAHA, Srivastava AK, Saber H, Alwaleed EA, Tran LSP (2017) Sargassum muticum and Jania rubens regulate amino acid metabolism to improve growth and alleviate salinity in chickpea. Sci Rep 7:10537.

Latz A, Mehlmer N, Zapf S, Mueller TD, Wurzinger B, et al. (2013) Salt stress triggers phosphorylation of the Arabidopsis vacuolar $\mathrm{K}^{+}$channel TPK1 by calcium-dependent protein kinases (CDPKs). Mol Plant 6:1274-1289.

Lehr A, Kirsch M, Viereck R, Schiemann J, Rausch T (1999) cDNA and genomic cloning of sugar beet V-type H-ATPase subunit $A$ and $c$ isoforms: evidence for coordinate expression during plant development and coordinate induction in response to high salinity. Plant Mol Biol 39:463-475.

Leng X, Wang P, Zhu X, Li X, Zheng T, Shangguan L, Fang J (2017) Ectopic expression of CSD1 and CSD2 targeting genes of miR398 in grapevine is associated with oxidative stress tolerance. Funct Integr Gen 17:697-710. 
1219 Li C, Zong Y, Wang Y, Jin S, Zhang D, Song Q, Zhang R, Gao C (2018a). Expanded base 1220 editing in rice and wheat using a Cas9-adenosine deaminase fusion. Genome biology, 19(1): 1221 59. doi:10.1186/s13059-018-1443-z

1222 Li JF, Aach J, Norville JE, McCormack M, Zhang D, Bush J, Sheen J (2013) Multiplex and 1223 homologous recombination-mediated plant genome editing via guide RNA/Cas9. Nat Biotechnol 31:688-691.

Li JY, He XW, Xu L, Zhou J, Wu P, Shou HX, Zhang FC (2008). Molecular and functional 1226 comparisons of the vacuolar $\mathrm{Na}^{+} / \mathrm{H}^{+}$exchangers originated from glycophytic and halophytic species. J Zhejiang Univ, Sci B 9:132-140.

Li K, Pang CH, Ding F, Sui N, Feng ZT, Wang BS (2012) Overexpression of Suaeda salsa stroma ascorbate peroxidase in Arabidopsis chloroplasts enhances salt tolerance of plants. S Afr J Bot 78:235-245.

Li QL, Xie JH, Ma XQ, Li D (2016) Molecular cloning of phosphoethanolamine Nmethyltransferase (PEAMT) gene and its promoter from the halophyte Suaeda liaotungensis and their response to salt stress. Acta Physiol Plant 38:39.

Li S, Zhang X, Wang W, Guo X, Wu Z, Du W, Zhao Y, Xia L (2018b). Expanding the scope of CRISPR/Cpf1-mediated genome editing in rice. Mol Plant 11(7):995-998

Li W, Deli W, Taicheng J, Qing C, Dongxu Y, Shoumin X, Bao L, Lixia L (2011) The vacuolar $\mathrm{Na}^{+} / \mathrm{H}^{+}$antiporter gene $S s N H X 1$ from the halophyte Salsola soda confers salt tolerance in transgenic alfalfa (Medicago sativa L.). Plant Mol Biol Rep 29:278-290.

Li W, Tran LSP (2017) Effects of ethylene on seed germination of halophyte plants under salt stress. In: Binder B, Eric Schaller G (eds) Ethylene Signaling: Methods in Molecular Biology, Humana Press, New York, NY. pp 253-259.

Li W, Wang T, Zhang Y, Li Y (2015) Overexpression of soybean miR172c confers tolerance to water deficit and salt stress, but increases ABA sensitivity in transgenic Arabidopsis thaliana. J Exp Bot 67:175-194.

Li XL, Yang X, Hu YX, Yu XD, Li QL (2014) A novel NAC transcription factor from Suaeda liaotungensis K. enhanced transgenic Arabidopsis drought, salt, and cold stress tolerance. Plant Cell Rep 33:767-778. 
Li Y, Zhang Y, Feng F, Liang D, Cheng L, Ma F, Shi S (2010) Overexpression of a Malus vacuolar $\mathrm{Na}^{+} / \mathrm{H}^{+}$antiporter gene $(M d N H X 1)$ in apple rootstock M.26 and its influence on salt tolerance. Plant Cell Tiss Org Cult 102:337-345.

Liang X, Liu Y, Xie L, Liu X, Wei Y, Zhou X, Zhang S (2015). A ribosomal protein AgRPS3aE from halophilic Aspergillus glaucus confers salt tolerance in heterologous organisms. Int J Mol Sci 16:3058-3070. doi: 10.3390/ijms16023058.

Liu C, Bai B, Skogerbø G, Cai L, Deng W, Zhang Y, Bu D, Zhao Y, Chen R (2005) NONCODE: an integrated knowledge database of non-coding RNAs. Nucleic Acids Res 33:D112-D115.

Liu HUA, Wang Q, Yu M, Zhang Y, Wu Y, Zhang H (2008) Transgenic salt-tolerant sugar beet (Beta vulgaris L.) constitutively expressing an Arabidopsis thaliana vacuolar $\mathrm{Na}^{+} / \mathrm{H}^{+}$ antiporter gene, AtNHX3, accumulates more soluble sugar but less salt in storage roots. Plant Cell Environ 31:1325-1334.

Liu J, Hua W, Zhan G, Wei F, Wang X, Liu G, Wang H (2010) Increasing seed mass and oil content in transgenic Arabidopsis by the overexpression of wril-like gene from Brassica napus. Plant Physiol Biochem 48:9-15.

Liu J, Zhu JK (1998). A calcium sensor homolog required for plant salt tolerance. Science 280: 1943-1945.

Liu JP, Ishitani M, Halfter U, Kim CS, Zhu JK (2000). The Arabidopsis thaliana SOS2 gene encodes a protein kinase that is required for salt tolerance. Proc Natl Acad Sci, USA 97: $3730-3734$.

Liu L, Wang Y, Dong YY, Fan XD, Liu XM, Yang J, Li HY (2011) Cloning of a vacuolar $\mathrm{H}^{+}$-pyrophosphatase gene from the halophyte Suaeda corniculata whose heterologous overexpression improves salt, saline-alkali and drought tolerance in Arabidopsis. J Integrat Plant Biol 53:731-742.

Liu N, Ni Z, Zhang H, Chen Q, Gao W, Cai Y, Li M, Sun G, Qu YY (2018) The gene encoding subunit A of the vacuolar $\mathrm{H}^{+}$-ATPase from cotton plays an important role in conferring tolerance to water deficit. Front Plant Sci 9:758. doi: 10.3389/fpls.2018.00758.

Liu XD, Xie L, Wei Y, Zhou X, Jia B, Liu J, Zhang S (2014) Abiotic stress resistance, a novel moonlighting function of ribosomal protein RPL44 in the halophilic fungus Aspergillus glaucus. Appl Environ Microbiol 80:4294-300. 
Lotfi A, Pervaiz T, Jiu S, Faghihi F, Jahanbakhshian Z, Khorzoghi EG, Fang J (2017) Role of microRNAs and their target genes in salinity response in plants. Plant Growth Regul 82:377-390.

Lou D, Wang H, Liang G, Yu D. (2017). OsSAPK2 Confers Abscisic Acid Sensitivity and Tolerance to Drought Stress in Rice. Front Plant Sci 8: 993. doi:10.3389/fpls.2017.00993

Lu W, Guo C, Li X, Duan W, Ma C, et al. (2014) Overexpression of TaNHX3, a vacuolar $\mathrm{Na}^{+} / \mathrm{H}^{+}$antiporter gene in wheat, enhances salt stress tolerance in tobacco by improving related physiological processes. Plant Physiol Biochem 76:17-28.

Lu Y and Zhu JK (2017) Precise editing of a target base in the rice genome using a modified CRISPR/Cas9 system. Mol Plant 10: 523-525.

Luo M, Zhao Y, Zhang R, Xing J, Duan M, Li J, Wang N, Wang W, Zhang S, Chen Z, Zhang H, Shi Z, Song W, Zhao J (2017) Mapping of a major QTL for salt tolerance of mature fieldgrown maize plants based on SNP markers. BMC Plant Biol 17:140

Lv S, Zhang K, Gao Q, Lian L, Song Y, Zhang J (2008) Overexpression of an H+-PPase gene from Thellungiella halophila in cotton enhances salt tolerance and improves growth and photosynthetic performance. Plant Cell Physiol 49:1150-1164.

Ma Q, Hu J, Zhou XR, Yuan HJ, Kumar T, Luan S, Wang SM (2017) ZxAKT1 is essential for $\mathrm{K}^{+}$ uptake and $\mathrm{K}^{+} / \mathrm{Na}^{+}$homeostasis in the succulent xerophyte Zygophyllum xanthoxylum. Plant J 90:48-60.

Ma X, Zhang Q, Zhu Q, Liu W, Chen Y, Qiu R, Liu YG (2015a) A robust CRISPR/Cas9 system for convenient, high-efficiency multiplex genome editing in monocot and dicot plants. Mol Plant 8:1274-84.

Ma, DM, Xu WR, Li HW, Jin FX, Guo LN, et al. (2014) Co-expression of the Arabidopsis SOS genes enhances salt tolerance in transgenic tall fescue (Festuca arundinacea Schreb.). Protoplasma 251:219-231.

Ma, J.T., Yin, C.C., Zhou, M.L., Wang, Z.L., \& Wu, Y.M. (2015b). A novel DREB transcription factor from Halimodendron halodendron leads to enhance drought and salt tolerance in Arabidopsis. Biol Plant 59:74-82.

Mann A, Kumar N, Lata C, Kumar A, Kumar A, Meena BL (2019) Functional annotation of differentially expressed genes under salt stress in Dichanthium annulatum. Plant Physiol Rep 24:104-111. 
1310 Maathuis FJM, Ahmad I, Patishtan J (2014) Regulation of $\mathrm{Na}^{+}$fluxes in plants. Front Plant Sci 5:467.

1312 Maeshima M (2000) Vacuolar $\mathrm{H}^{+}$-pyrophosphatase. Biochim Biophys Acta 1465:37-51.

1313 Maheshwari P, Kiran B, Punita DL, Kavi Kishor PB (2017) Overexpression of SbAP37 in rice 1314 alleviates concurrent imposition of combination stresses and modulates different sets of leaf protein profiles. Plant Cell Rep 36:773-786.

Mishra S, Alavilli H, Lee BH, Panda SK, Sahoo L (2014) Cloning and functional

Mallikarjuna G, Mallikarjuna K, Reddy MK, Kaul T (2011) Expression of OsDREB2A transcription factor confers enhanced dehydration and salt stress tolerance in rice (Oryza sativa L.). Biotechnol Lett 33:1689-1697.

Mansour MM (2014) The plasma membrane transport systems and adaptation to salinity. J Plant Physiol 171:1787-1800.

Mao X, Chen S, Li A, Zhai C, Jing R (2014) Novel NAC transcription factor TaNAC67 confers enhanced multi-abiotic stress tolerances in Arabidopsis. PLoS One 9:e84359.

Martinez-Ballesta M, Del C, Carvajal M (2014) New challenges in plant aquaporin biotechnology. Plant Sci 217-218: 71-77.

Matsukura S, Mizoi J, Yoshida T, Todaka D, Ito Y, Maruyama K, Shinozaki K, et al. (2010). Comprehensive analysis of rice DREB2-type genes that encode transcription factors involved in the expression of abiotic stress responsive genes. Mol Genet Genomics 283: 185-196.

Meng M, Gou L, Chen D, Mao C, Jin Y, Wu P, Chen M (2011) PmiRKB: a plant microRNA knowledge base. Nucleic Acids Res 39:D181-D187.

Merlot S, Leonhardt N, Fenzi F, Valon C, Costa M, Piette L, Leung J (2007) Constitutive activation of a plasma membrane $\mathrm{H}^{+}$-ATPase prevents abscisic acid-mediated stomatal closure. EMBO J 26:3216-3226.

Mian A, Oomen RJFJ, Isayenkov S, Sentenac H, Maathuis FJM, Very AA (2011) Overexpression of an $\mathrm{Na}^{+}$-and $\mathrm{K}^{+}$-permeable HKT transporter in barley improves salt tolerance. Plant J 68:468-479. characterization of a vacuolar $\mathrm{Na}^{+} / \mathrm{H}^{+}$antiporter gene from mungbean $(\mathrm{VrNHXI})$ and its ectopic expression enhanced salt tolerance in Arabidopsis thaliana. PLoS One 9:e106678. 
1341 Mishra A, Tanna B (2017) Halophytes: Potential resources for salt stress tolerance genes and 1342 promoters. Front Plant Sci 8:829.

1343 Mitsuda N, Enami K, Nakata M, Takeyasu K, Sato MH (2001) Novel type Arabidopsis thaliana $1344 \mathrm{H}^{+}$-PPase is localized to the Golgi apparatus. FEBS Lett 488:29-33.

1345 Mochida K, Yoshida T, Sakurai T, Yamaguchi-Shinozaki K, Shinozaki K, Tran LS (2011) In transcription factors from six major Gramineae plants. DNA Res 18:321-332.

Moghaieb RE, Nakamura A, Saneoka H, Fujita K (2011) Evaluation of salt tolerance in ectoinetransgenic tomato plants (Lycopersicon esculentum) in terms of photosynthesis, osmotic adjustment, and carbon partitioning. GM Crops 2(1):58-65.

Møller IS, Gilliham M, Jha D, Mayo GM, Roy SJ, Coates JC, Haseloff J, Tester M (2009) Shoot $\mathrm{Na}^{+}$exclusion and increased salinity tolerance engineered by cell type-specific alteration of $\mathrm{Na}^{+}$transport in Arabidopsis. Plant Cell 21:2163-2178.

Morton MJL, Awlia M, Al-Tamimi N, Saade S, Pailles Y, Negrão S, Tester M (2019) Salt stress under the scalpel - dissecting the genetics of salt tolerance. Plant J 97(1):148-163.

Müller M, Kunz HH, Schroeder JI, Kemp G, Young HS, Neuhaus HE (2014) Decreased capacity for sodium export out of Arabidopsis chloroplasts impairs salt tolerance, photosynthesis and plant performance. Plant J 78:646-658.

Munns R, James RA, Xu B, Athman A, Conn SJ, et al. (2012). Wheat grain yield on saline soils is improved by an ancestral $\mathrm{Na}^{+}$transporter gene. Nat Biotechnol 30:360-364.

Narasimhan ML, Binzel ML, Perez-Prat E, Chen Z, Nelson DE, Singh NK, Bressan RB, Hasegawa PM (1991) $\mathrm{NaCl}$ regulation of tonoplast ATPase 70-kilodalton subunit mRNA in tobacco cells. Plant Physiol 97:562-568.

Nguyen HM, Sako K, Matsui A, Suzuki Y, Mostofa MG, Ha CV, Seki M (2017) Ethanol enhances high-salinity stress tolerance by detoxifying reactive oxygen species in Arabidopsis thaliana and rice. Front Plant Sci 8:1001.

Niczyj M, Champagne A, Alam I, Nader J, Boutr M (2016) Expression of a constitutively activated plasma membrane $\mathrm{H}^{+}$-ATPase in Nicotiana tabacum BY-2 cells results in cell expansion. Planta 244:1109-1124

Nieves-Cordones M, Martínez V, Benito B, Rubio F (2016) Comparison between Arabidopsis and rice for main pathways of $\mathrm{K}^{+}$and $\mathrm{Na}^{+}$uptake by roots. Front Plant Sci 7:992. 
1372 Nishiyama R, Le DT, Watanabe Y, Matsui A, Tanaka M, Seki M, Tran LSP (2012)

1373

1374

1375

1376

1377

1378

1379

1380

1381

1382

1383

1384

1385

1386

1387

1388

1389

1390

1391

1392

1393

1394

1395

1396

1397

1398

1399

1400
Transcriptome analyses of a salt-tolerant cytokinin-deficient mutant reveal differential regulation of salt stress response by cytokinin deficiency. PLoS One 7:e32124.

Niu X, Xiong F, Liu J, Sui Y, Zeng Z, Lu BR, Liu Y (2014) Co-expression of ApGSMT and ApDMT promotes biosynthesis of glycine betaine in rice (Oryza sativa L.) and enhances salt and cold tolerance. Environ Exp Bot 104:16-25.

Ohta M, Hayashi Y, Nakashima A, Hamada A, Tanaka A, Nakamura T, Hayakawa T (2002) Introduction of a $\mathrm{Na}^{+} / \mathrm{H}^{+}$antiporter gene from Atriplex gmelini confers salt tolerance to rice. FEBS Lett 532:279-282.

Osakabe Y, Watanabe T, Sugano SS, Ueta R, Ishihara R, Shinozaki K, Osakabe K (2016) Optimization of CRISPR/Cas9 genome editing to modify abiotic stress responses in plants. Sci Rep 6:26685.

Ottens F, Gehring NH (2016). Physiological and pathophysiological role of nonsense-mediated mRNA decay. Pflugers Arch. 468: 1013-1028.

Padmanaban S, Lin X, Perera I, Kawamura Y, Sze H (2004) Differential expression of vacuolar $\mathrm{H}^{+}$-ATPase subunit $\mathrm{c}$ genes in tissues active in membrane trafficking and their roles in plant growth as revealed by RNAi. Plant Physiol 134:1514-1626.

Pan JW, Tao JJ, Cheng TC, Bian XH, Wei W, Zhang WK, Zhang JS (2016) Soybean miR172a improves salt tolerance and can function as a long-distance signal. Mol Plant 9:13371340.

Pandey S, Patel MK, Mishra A, Jha B (2016) In planta transformed cumin (Cuminum cyminum L.) plants, overexpressing the SbNHX1 gene showed enhanced salt endurance. PLoS One, 11:e0159349.

Parks GE, Dietrich MA, Schumaker KS (2002) Increased vacuolar $\mathrm{Na}^{+} / \mathrm{H}^{+}$exchange activity in Salicornia bigelovii Torr. in response to salt. J Exp Bot 53:1055-1065.

Pasapula V, Shen G, Kuppu S, Paez-Valencia J, Mendoza M, Hou P, Payton P (2011) Expression of an Arabidopsis vacuolar $\mathrm{H}^{+}$-pyrophosphatase gene (AVP1) in cotton improves drought- and salt tolerance and increases fiber yield in the field conditions. Plant Biotechnol J 9:88-99. 
1401 Patel MK, Joshi M, Mishra A, Jha B (2015) Ectopic expression of SbNHXlgene in transgenic castor (Ricinus communis L.) enhances salt stress by modulating physiological process. Plant Cell Tiss Organ Cult 122:477-490.

1404 Patra D, Fasold M, Langenberger D, Steger G, Grosse I, Stadler PF (2014) plantDARIO: web 1405 based quantitative and qualitative analysis of small RNA-seq data in plants. Front Plant Sci 5:708 https://doi.org/10.3389/fpls.2014.00708.

Pehlivan N, Sun L, Jarrett P, Yang X, Mishra N, et al. (2016) Co-overexpressing a plasma membrane and a vacuolar membrane sodium/proton antiporter significantly improves salt tolerance in transgenic Arabidopsis plants. Plant Cell Physiol 57:1069-1084.

Pizzio GA, Paez-Valencia J, Khadilkar AS, Regmi K, Patron-Soberano A, et al. (2015) Arabidopsis type I proton-pumping pyrophosphatase expresses strongly in phloem, where it is required for pyrophosphate metabolism and photosynthate portioning. Plant Physiol 167:1541-1553.

Plett D, Safwat G, Gilliham M, Moller IS, Roy S, Shirley N, Tester M (2010) Improved salinity tolerance of rice through cell type-specific expression of AtHKT1,1. PLoS One, 5:e12571.

Pose D, Verhage L, Ott F, Yant L, Mathieu J, Angenent GC, Immink RG, et al. (2013). Temperature-dependent regulation of flowering by antagonistic FLM variants. Nature 503: 414-417.

Puchta H (2017) Applying CRISPR/Cas for genome engineering in plants: the best is yet to come. Curr Opin Plant Biol 36:1-8.

Qin H, Gu Q, Kuppu S, Sun L, Zhu X, et al. (2013) Expression of the Arabidopsis vacuolar $\mathrm{H}^{+}$pyrophosphatase gene AVP1 in peanut to improve drought and salt tolerance. Plant Biotechnol Rep 7:345-355.

Qiu QS, Guo Y, Quintero FJ, Pardo JM, Schumaker KS, Zhu JK (2004). Regulation of vacuolar $\mathrm{Na}^{+} / \mathrm{H}^{+}$exchange in Arabidopsis thaliana by the salt-overly-sensitive (SOS) pathway. $\mathrm{J}$ Biol Chem 279: 207-215.

Queirós F, Fontes N, Silva P, Almeida D, Maeshima M, Gerós H, Fidalgo F (2009) Activity of tonoplast proton pumps and $\mathrm{Na}^{+} / \mathrm{H}^{+}$exchange in potato cell cultures is modulated by salt. J Exp Bot 60:1363-1374. 
1431 Raheem A, Ali B (2015) Halotolerant rhizobacteria: beneficial plant metabolites and growth enhancement of Triticum aestivum L. in salt-amended soils. Arch Agron Soil Sci 61:1691-1705.

Rahman H, Ramanathan V, Nallathambi J, Duraialagaraja S, Muthurajan R (2016) Overexpression of a NAC 67 transcription factor from finger millet (Eleusine coracana L.) confers tolerance against salinity and drought stress in rice. BMC Biotechnol 16:35.

Rahman MM, Rahman MA, Miah MG, Saha SR, Karim MA, Mostofa MG (2017) Mechanistic insight into salt tolerance of Acacia auriculiformis: The importance of ion selectivity, osmoprotection, tissue tolerance, and $\mathrm{Na}^{+}$exclusion. Front Plant Sci 8:155.

Rajagopal D, Agarwal P, Tyagi W, Singla-Pareek SL, Reddy MK, Sopory SK (2007) Pennisetum glaucum $\mathrm{Na}^{+} / \mathrm{H}^{+}$antiporter confers high level of salinity tolerance in transgenic Brassica juncea. Mol Breed 19:137-151.

Ratajczak R (2000) Structure, function and regulation of the plant vacuolar $\mathrm{H}^{+}$-translocating ATPase. Biochim Biophys Acta 1465:17-36.

Reddy ASN, Marquez Y, Kalyna M, Bartab A (2013). Complexity of the alternative splicing landscape in plants. Plant Cell 25: 3657-3683.

Ren ZH, Gao JP, Li LG, Cai XL, Huang W, Chao DY, Zhu MZ, Wang ZY, Luan S, Lin HX (2005) A rice quantitative trait locus for salt tolerance encodes a sodium transporter. Nat Genet 37:1141-1146.

RNAcentral (2016) RNAcentral: a comprehensive database of non-coding RNA sequences The RNAcentral Consortium. Nucleic Acids Res 45:D128-D134.

Rodríguez-Rosales MP, Jiang X, Gálvez FJ, Aranda MN, Cubero B, Venema K (2008) Overexpression of the tomato $\mathrm{K}^{+} / \mathrm{H}^{+}$antiporter LeNHX2 confers salt tolerance by improving potassium compartmentalization. New Phytol 179:366-377.

Roy SJ, Negrao S, Tester M (2014) Salt resistant crop plants. Curr Opin Biotechnol 26:115-124.

Saad ASI, Li X, Li HP, Huang T, Gao CS, Guo MW, Liao YC (2013) A rice stress-responsive NAC gene enhances tolerance of transgenic wheat to drought and salt stresses. Plant Sci 203:33-40.

Sarafian V, Kim Y, Poole RJ, Rea PA (1992) Molecular cloning and sequence of cDNA encoding the pyrophosphate-energized vacuolar membrane proton pump of Arabidopsis thaliana. Proc Natl Acad Sci USA, 89:1775-1779. 
1462 Saurabh S, Vidyarthi AS, Prasad D (2014) RNA interference: concept to reality in crop 1463 improvement. Planta 239:543-64.

1464 Schilling RK, Marschner P, Shavrukov Y, Berger B, Tester M, Roy SJ, Plett DC (2014) 1465 Expression of the Arabidopsis vacuolar $\mathrm{H}^{+}$-pyrophosphatase gene (AVP1) improves the 1466 1467 shoot biomass of transgenic barley and increases grain yield in a saline field. Plant Biotechnol J 12:378-386.

Schmidt R, Mieulet D, Hubberten HM, Obata T, Hoefgen R, Fernie AR, Mueller-Roeber B (2013) SALT-RESPONSIVE ERF1 regulates reactive oxygen species-dependent signaling during the initial response to salt stress in rice. Plant Cell 25:2115-2131.

Schumacher K, Vafeados D, McCarthy M, Sze H, Wilkins T, Chory J (1999) The Arabidopsis det3 mutant reveals a central role for the vacuolar $\mathrm{H}^{+}$-ATPase in plant growth and development. Genes Develep 13:3259-3270.

Seo PJ, Hong SY, Kim SG, Park CM (2011). Competitive inhibition of transcription factors by small interfering peptides. Trends Plant Sci 16: 541-549.

Shabala S, Bose J, Hedrich R (2014) Salt bladders: do they matter? Trends Plant Sci 19:687-691.

Sharma S, Kulkarni J, Jha B (2016) Halotolerant rhizobacteria promote growth and enhance salinity tolerance in peanut. Front Microbiol 7:1600.

Shavrukov Y (2013) Salt stress or salt shock: which genes are we studying? J Exp Bot 64:119127.

Shen G, Wei J, Qiu X, Hu R, Kuppu S, et al. (2015) Co-overexpression of AVP1 and AtNHX1 in cotton further improves drought and salt tolerance in transgenic cotton plants. Plant Mol Biol Rep 33:167-177.

Shi H, We SJ, Zhu JK (2003). Overexpression of a plasma membrane $\mathrm{Na}^{+} / \mathrm{H}^{+}$antiporter improves salt tolerance in Arabidopsis. Nature Biotechnol 21: 81-85.

Shi J, Gao H, Wang H, Lafitte HR, Archibald RL, Yang M, Habben JE (2017) ARGOS8 variants generated by CRISPR/Cas9 improve maize grain yield under field drought stress conditions. Plant Biotechnol J 15:207-216.

Shi LY, Li HQ, Pan XP, Wu GJ, Li MR (2008) Improvement of Torenia fournieri salinity tolerance by expression of Arabidopsis AtNHX5. Funct Plant Biol 35:185-192.

Shriram V, Kumar V, Devarumath RM, Khare T, Wani SH (2016) MicroRNAs as potent targets for abiotic stress tolerance in plants. Front Plant Sci 7:817. 
1493 Shrivastava P, Kumar R (2015) Soil salinity: A serious environmental issue and plant growth 1494 promoting bacteria as one of the tools for its alleviation. Saudi J Biol Sci 22(2):123-131.

1495 Shukla PS, Gupta K, Agarwal P, Jha B, Agarwal PK (2015) Overexpression of a novel 1496 SbMYB15 from Salicornia brachiata confers salinity and dehydration tolerance by reduced oxidative damage and improved photosynthesis in transgenic tobacco. Planta 242:1291-1308.

Silva P, Gerós H (2009) Regulation by salt of vacuolar $\mathrm{H}^{+}$-ATPase and $\mathrm{H}^{+}$-pyrophosphatase activities and $\mathrm{Na}^{+} / \mathrm{H}^{+}$exchange. Plant Signal Behav 4:718-726.

Singh N, Mishra A, Jha B (2014) Ectopic over-expression of peroxisomal ascorbate peroxidase

Singh N, Mishra A, Jha B (2014) Over-expression of the peroxisomal ascorbate peroxidase (SbpAPX) gene cloned from halophyte Salicornia brachiata confers salt and drought stress tolerance in transgenic tobacco. Marine Biotechnol 16:321-332.

Singh VK, Mishra A, Haque I, Jha B (2016) A novel transcription factor-like gene SbSDRlacts as a molecular switch and confers salt and osmotic endurance to transgenic tobacco. Sci Rep 6:31686. DOI: 10.1038/srep31686.

Song A, An J, Guan Z, Jiang J, Chen F, et al. (2014) The constitutive expression of a two transgene construct enhances the abiotic stress tolerance of chrysanthemum. Plant Physiol Biochem 80:114-120.

Song X, Fang J, Han X, He X, Liu M, Hu J, Zhuo R (2016) Overexpression of quinone reductase from Salix matsudana Koidz enhances salt tolerance in transgenic Arabidopsis thaliana. Gene 576:520-527.

Spring S, Scheuner C, Lapidus A, Lucas S, del Rio, TG, Tice H, Klenk HP (2010) The genome sequence of Methanohalophilus mahii SLP $\mathrm{T}$ reveals differences in the energy metabolism among members of the Methano sarcinaceae inhabiting freshwater and saline environments. Archaea 2010:690737.

Srivastava A K, Shankar A, Nalini CAK, Sharma M, Jung KH, Suprasanna P, Pandey GK (2020) Emerging concepts of potassium homeostasis in plants. J Exp Bot 71 ( 2):608-619 Staiger D, Brown JWS (2013). Alternative splicing at the intersection of biological timing, development, and stress responses. Plant Cell 25: 3640-3656. 
1524 Sugio A, Dreos R, Aparicio F, Maule AJ (2009). The cytosolic protein response as a 1525 subcomponent of the wider heat shock response in Arabidopsis. Plant Cell 21: 642-654.

1526 Sun J, Dai S, Wang R, Chen S, Li N, et al. (2009) Calcium mediates root $\mathrm{K}^{+} / \mathrm{Na}^{+}$homeostasis in 1527 poplar species differing in salt tolerance. Tree Physiol 29:1175-1186.

1528 Sun MH, Ma QJ, Liu X, Zhu XP, Hu DG, Hao YJ (2017) Molecular cloning and functional 1529 characterization of MdNHX1 reveals its involvement in salt tolerance in apple calli and Arabidopsis. Sci Hort 215:126-133.

Sun Q, Gao F, Zhao L, Li K, Zhang J (2010) Identification of a new 130 bp cis-acting element in the TsVP1 promoter involved in the salt stress response from Thellungiella halophila. BMC Plant Biol 10:90.

Sun X, Dong B, Yin L, Zhang R, Du W, Liu D, Shi N, Li A, Liang Y, Mao L (2013) PMTED: a plant microRNA target expression database. BMC Bioinform, 14:174

Sun X, Xu L, Wang Y, Luo X, Zhu X, Kinuthia KB, Liu L (2016) Transcriptome-based gene expression profiling identifies differentially expressed genes critical for salt stress response in radish (Raphanus sativus L.). Plant Cell Rep 35:329-346.

Sunkar R, Li YF, Jagadeeswaran G (2012) Functions of microRNAs in plant stress responses. Trends Plant Sc 17:196-203.

Suo J, Zhao Q, David L, Chen S, Dai S (2017) Salinity response in chloroplasts: insights from gene characterization. Int J Mol Sci 18:1011.

Syed NH, Kalyna M, Marquez Y, Barta A, Brown JW (2012). Alternative splicing in plantscoming of age. Trends Plant Sci. 17: 616-623.

Szabó I, Spetea C (2017) Impact of the ion transportome of chloroplasts on the optimization of photosynthesis. J Exp Bot 68:3115-3128

Tang X, Lowder LG, Zhang T, Malzahn AA, Zheng X, Voytas DF, Zhong Z, Chen Y, Ren Q, Li Q, Kirkland ER, Zhang Y, Qi Y (2017) A CRISPR-Cpf1 system for efficient genome editing and transcriptional repression in plants. Nat Plants 3:17018

Thomson MJ, de Ocampo M, Egdane J, Rahman MA, Sajise AG, Adorada DL (2010) Characterizing the Saltol quantitative trait locus for salinity tolerance in rice. Rice 3:148160 
1553 Tian N, Wang J, Xu ZQ (2011) Overexpression of $\mathrm{Na}^{+} / \mathrm{H}^{+}$antiporter gene AtNHX1 from Arabidopsis thaliana improves the salt tolerance of kiwifruit (Actinidia deliciosa). S Afr J Bot 77:160-169.

Tiwari V, Chaturvedi AK, Mishra A, Jha B (2015) Introgression of the SbASR-1 gene cloned from a halophyte Salicornia brachiata enhances salinity and drought endurance in transgenic groundnut (Arachis hypogaea) and acts as a transcription factor. PLoS One 10:e0131567.

Tiwari V, Patel MK, Chaturvedi AK, Mishra A, Jha B (2016) Functional characterization of the tau class glutathione-S-transferases gene (SbGSTU) promoter of Salicornia brachiata under salinity and osmotic stress. PLoS One 11:e0148494.

Tran LSP, Mochida K (2010) Identification and prediction of abiotic stress responsive transcription factors involved in abiotic stress signaling in soybean. Plant Signal Behav 5:255-257.

Tran LSP, Nishiyama R, Yamaguchi-Shinozaki K, Shinozaki K (2010) Potential utilization of NAC transcription factors to enhance abiotic stress tolerance in plants by biotechnological approach. GM Crops 1:32-39.

Tyagi W, Rajagoal D, Singla-Pareek SL, Reddy MK, Sopory SK (2005) Cloning and regulation of a stress-regulated Pennisetum glaucum vacuolar ATPase c gene and characterization of its promoter that is expressed in shoot hairs and floral organs. Plant Cell Physiol 46:1411-1422.

Undurraga SF, Santos MP, Paez-Valencia J, Yang H, Hepler PK, Facanha AR, Hirschi KD, Gaxiola RA (2012) Arabidopsis sodium dependent and independent phenotypes triggered by $\mathrm{H}^{+}$-PPase up-regulation are SOS1 dependent. Plant Sci 183:96-105.

Van de Wiel, CCM, Schaart JG, Lotz LAP, Smulders MJM (2017) New traits in crops produced by genome editing techniques based on deletions. Plant Biotechnol Rep 11:1-8.

Verma D, Singla-Pareek SL, Rajagopal D, Reddy MK, Sopory SK (2007) Functional validation of a novel isoform of $\mathrm{Na}^{+} / \mathrm{H}^{+}$antiporter from Pennisetum glaucum for enhancing salinity tolerance in rice. J Biosci 32:621-628.

Vitart V, Baxter I, Doerner P, Harper JF (2001) Evidence for a role in growth and salt resistance of a plasma membrane $\mathrm{H}^{+}$-ATPase in the root endodermis. Plant $\mathrm{J}$ 27:191-201. 
1583 Volkov V (2015) Salinity tolerance in plants. Quantitative approach to ion transport starting from 1584 halophytes and stepping to genetic and protein engineering for manipulating ion fluxes. Front Plant Sci 6:873.

Volkov V, Amtmann A (2006) Thellungiella halophila, a salt-tolerant relative of Arabidopsis thaliana, has specific root ion-channel features supporting $\mathrm{K}+/ \mathrm{Na}+$ homeostasis under salinity stress. Plant Journal 48:342-353.

Volkov V, Wang B, Dominy PJ, Fricke W, Amtmann A (2004) Thellungiella halophila, a salt tolerant relative of Arabidopsis thaliana, possesses effective mechanisms to discriminate between potassium and sodium. Plant Cell Environ 27:1-14.

Voytas DF (2013) Plant genome engineering with sequence-specific nucleases. An Rev Plant Biol 64:327-350.

1594 Wang FW, Wang ML, Guo C, Wang N, Li XW, Chen H, Li HY (2016a) Cloning and characterization of a novel betaine aldehyde dehydrogenase gene from Suaeda corniculata. Genet Mol Res 15:gmr.15027848.

Wang CS, Jiang QT, Ma J, Wang XY, Wang JR, Chen GY, Wei YM (2016b) Characterization and expression analyses of the $\mathrm{H}^{+}$-pyrophosphatase gene in rye. J Genet 95:565-572

1599 Wang J, Zhou A, Li Y, Li S, Zhang X, Che D (2016) Overexpression of IrlVHA-c, a vacuolartype $\mathrm{H}^{+}$-ATPase c subunit gene from Iris lactea, enhances salt tolerance in tobacco. Plant Mol Biol Rep 34:877-885.

Wang M, Mao Y, Lu Y, Wang Z, Tao X, Zhu JK (2018) Multiplex gene editing in rice with simplified CRISPR-Cpf1 and CRISPR-Cas9 systems. J Integr Plant Biol 2018 60: 626631.

1611 maritima. Plant Physiology 145:559-571. 
1612 Wang X, Wu F, Xie Q, Wang H, Wang Y, Yue Y, Gahura O, Ma S, Liu L, Cao Y, Jiao Y, Puta F, McClung CR, Xu X, Ma L (2012) SKIP is a component of the spliceosome linking alternative splicing and the circadian clock in Arabidopsis. Plant Cell 24: 3278-3295.

Wang X, Yang R, Wang B, Liu G, Yang C, Cheng Y (2011) Functional characterization of a 1616 plasma membrane $\mathrm{Na}^{+} / \mathrm{H}^{+}$antiporter from alkali grass (Puccinellia tenuiflora). Mol Biol Rep 38:4813-4822.

Wei Q, Hu P, Kuai BK (2012) Ectopic expression of an Ammopiptanthus mongolicus $\mathrm{H}^{+}-$ pyrophosphatase gene enhances drought and salt tolerance in Arabidopsis. Plant Cell Tiss Org Cult 110:359-369.

Wang YC, Qu GZ, Li HY, Wu, YJ, Wang C, Liu GF, Yang CP (2010) Enhanced salt tolerance of transgenic poplar plants expressing a manganese superoxide dismutase from Tamarix androssowii. Mol Biol Rep 37:1119-1124.

Wani SH, Kumar V, Shriram V, Sah SK (2016) Phytohormones and their metabolic engineering for abiotic stress tolerance in crop plants. Crop J 4:162-176.

Weiner H, Stitt M, Heldt HW (1987) Subcellular compartmentation of pyrophosphate and pyrophosphatase in leaves. Biochem Biophys Acta 893:13-21.

Wu C, Gao X, Kong X, Zhao Y, Zhang H (2009) Molecular cloning and functional analysis of a $\mathrm{Na}^{+} / \mathrm{H}^{+}$antiporter gene ThNHX1 from a halophytic plant Thellungiella halophila Chunxia. Plant Mol Biol Rep 27:1-12.

Wu GQ, Feng RJ, Wang SM, Wang CM, Bao AK, Wei L, Yuan HJ (2015) Co-expression of xerophyte Zygophyllum xanthoxylum ZxNHX and ZxVP1-1 confers enhanced salinity tolerance in chimeric sugar beet (Beta vulgaris L.). Front Plant Sci 6:581.

Wu HJ, Zhang Z, Wang JY, Oh DH, Dassanayake M, Liu B, Xie Q (2012) Insights into salt tolerance from the genome of Thellungiella salsuginea. Proc Natl Acad Sci USA 109:12219-12224.

Wu W, Su Q, Xia XY, Wang Y, Luan YS, An LJ (2008) The Suaeda liaotungensis kitag betaine aldehyde dehydrogenase gene improves salt tolerance of transgenic maize mediated with minimum linear length of DNA fragment. Euphytica 159:17-25.

Wu XX, Li J, Wu XD, Liu Q, Wang ZK, et al. (2016) Ectopic expression of Arabidopsis thaliana $\mathrm{Na}^{+}\left(\mathrm{K}^{+}\right) / \mathrm{H}^{+}$antiporter gene, AtNHX5, enhances soybean salt tolerance. Genet Mol Res 15:1-12. 
1643 Xiong H, Li J, Liu P, Duan J, Zhao Y, Guo X, Li Z (2014) Overexpression of OsMYB48-1, a 1644 novel MYB-related transcription factor, enhances drought and salinity tolerance in rice. PLoS One 9:e92913.

1646 Xu C, Zheng L, Gao C, Wang C, Liu G, Jiang J, Wang Y (2011) Overexpression of a vacuolar $\mathrm{H}^{+}$-ATPase $c$ subunit gene mediates physiological changes leading to enhanced salt tolerance in transgenic tobacco. Plant Mol Biol Rep 29:424-430.

1649 Yadav NS, Shukla PS, Jha A, Agarwal PK, Jha B (2012) The SbSOSl gene from the extreme 1650 halophyte Salicornia brachiata enhances $\mathrm{Na}^{+}$loading in xylem and confers salt tolerance in transgenic tobacco. BMC Plant Biol 12:188.

1652 Yang A, Akhtar SS, Iqbal S, Amjad M, Naveed M, Zahir ZA, Jacobsen SE (2016) Enhancing 1653 salt tolerance in quinoa by halotolerant bacterial inoculation. Funct Plant Biol 43:632-42.

1654 Yang A, Dai X, Zhang WX (2012) A R2R3-type MYB gene, OsMYB2, is involved in salt, cold, 1655 and dehydration tolerance in rice. J Exp Bot 63:2541-2556.

1656 Yang Q, Chen ZZ, Zhou XF, Yin HB, Li X, et al. (2009) Overexpression of SOS (Salt Overly 1657 Sensitive) genes increases salt tolerance in transgenic Arabidopsis. Mol Plant 2:22-31.

1658 Yang W, Fan T, Hu X, Cheng T, Zhang M (2017) Overexpressing osa-miR171c decreases salt 1659 stress tolerance in rice. J Plant Biol 60:485-492.

1660 Yang X, Li L (2011) miRDeep-P: a computational tool for analyzing the microRNA 1661 transcriptome in plants. Bioinformatics 27:2614-2615.

1662 Yang Y, Tang RJ, Li B, Wang HH, Jin YL, et al. (2015) Overexpression of a Populus 1663 trichocarpa $\mathrm{H}^{+}$-pyrophosphatase gene PtVP1. 1 confers salt tolerance on transgenic 1664 poplar. Tree Physiol 35:663-677.

1665 Yao MH, Zeng Y, Liu L, Huang Y, Zhao E, Zhang F (2012) Overexpression of the halophyte 1666 Kalidium foliatum $\mathrm{H}^{+}$-pyrophosphatase gene confers salt and drought tolerance in 1667 Arabidopsis thaliana. Mol Biol Rep 39:7989-7996.

1668 Yarra R, He SJ, Abbagani S, Ma B, Bulle M, Zhang WK (2012) Overexpression of a wheat $1669 \mathrm{Na}^{+} / \mathrm{H}^{+}$antiporter gene (TaNHX2) enhances tolerance to salt stress in transgenic tomato 1670 1671 Yi X, Zhang Z, Ling Y, Xu W, Su Z (2015) PNRD: a plant non-coding RNA database. Nucleic 1672 Acids Res 43:D982-D989. 
1673 Yu X, Liu Y, Wang S, Tao Y, Wang Z, Shu Y, Ma H (2016) CarNAC4, a NAC-type chickpea 1674 transcription factor conferring enhanced drought and salt stress tolerances in Arabidopsis. Plant Cell Rep 35:613-627.

1676 Yuan S, Li Z, Li D, Yuan N, Hu Q, Luo H (2015) Constitutive expression of rice microRNA528 alters plant development and enhances tolerance to salinity stress and nitrogen starvation in creeping bentgrass. Plant Physiol 169:576-593.

1679 Yue Y, Zhang M, Zhang J, Duan L, Li Z (2012) SOS1 gene overexpression increased salt 1680 tolerance in transgenic tobacco by maintaining a higher $\mathrm{K}^{+} / \mathrm{Na}^{+}$ratio. $\mathrm{J}$ Plant Physiol 169:255-261.

1682 Zhang B (2015) MicroRNA: a new target for improving plant tolerance to abiotic stress. J Exp 1683 Bot 66:1749-1761.

1684 Zhang B, Wang Q (2016) MicroRNA, a new target for engineering new crop cultivars. 1685 Bioengineered 7:7-10.

1686 Zhang GH, Su Q, An LJ, Wu S (2008) Characterization and expression of a vacuolar $\mathrm{Na}^{+} / \mathrm{H}^{+}$ 1687 antiporter gene from the monocot halophyte Aeluropus littoralis. Plant Physiol Biochem 46:117-126.

Zhang HX, Blumwald E (2001). Transgenic salt-tolerant tomato plants accumulate salt in foliage but not in fruit. Nat Biotechnol 19: 765-768.

1691 Zhang JL, Flowers TJ, Wang SM (2010) Mechanisms of sodium uptake by roots of higher 1692 plants. Plant Soil 326:45-60.

1693 Zhang LQ, Niu YD, Huridu H, Hao JF, Qi Z, Hasi A (2014c) Salicornia europaea L. $\mathrm{Na}^{+} / \mathrm{H}^{+}$ 1694 antiporter gene improves salt tolerance in transgenic alfalfa (Medicago sativa L.). Genet 1695 Mol Res 13:5350-5360.

1696 Zhang M, Smith JAC, Harberd NP, Jiang C (2016) The regulatory roles of ethylene and reactive 1697 oxygen species (ROS) in plant salt stress responses. Plant Mol Biol 91:651-659.

1698 Zhang WD, Wang P, Bao Z, Ma Q, Duan LJ, Bao AK, Zhang JL, Wang SM (2017) SOS1, 1699 HKT1,5, and NHX1 synergistically modulate $\mathrm{Na}^{+}$homeostasis in the halophytic grass $1700 \quad$ Puccinellia tenuiflora. Front Plant Sci 8:576.

1701 Zhang X, Wang H, Liu S, Takano T (2014a) Cloning and characterization of a plasma membrane $1702 \quad \mathrm{H}^{+}$-ATPase (PMA) gene from a salt-tolerant plant Chloris virgata. Mol Soil Biol 5:16-22. 
1703 Zhang X, Zhang L, Dong F, Gao J, Galbraith DW, Song CP (2001) Hydrogen peroxide is 1704

1705 involved in abscisic acid-induced stomatal closure in Vicia faba. Plant Physiol 126:14381448.

1706

Zhang X, Zou Z, Zhang J, Zhang Y, Han Q, Hu T, Ye Z (2011) Over-expression of sly-miR156a 1707 in tomato results in multiple vegetative and reproductive trait alterations and partial phenocopy of the sft mutant. FEBS Lett 585:435-439.

Zhang XH, Li B, Hu YG, Chen L, Min DH (2014b) The wheat $E$ subunit of V-type $\mathrm{H}^{+}$-ATPase is involved in the plant response to osmotic stress. Int J Mol Sci 15:16196-16210.

Zhang Y, Li Y, Lai J, Zhang H, Liu Y, Liang L, Xie Q (2012) Ectopic expression of a LEA protein gene TsLEA1 from Thellungiella salsuginea confers salt-tolerance in yeast and Arabidopsis. Mol Biol Rep 39:4627-4633.

Zhang YC, Yu Y, Wang CY, Li ZY, Liu Q, Xu J, Xin P (2013) Overexpression of microRNA OsmiR397 improves rice yield by increasing grain size and promoting panicle branching. Nat Biotechnol 31:848-852.

Zhang Y, Zhang H, Liu Z, Li H, Guo X, Li G (2015) The wheat NHX antiporter gene TaNHX2 confers salt tolerance in transgenic alfalfa by increasing the retention capacity of intracellular potassium. Plant Mol Biol 87:317-337.

Zhao FY, Zhang XJ, Li PH, Zhao YX, Zhang H (2006) Co-expression of the Suaeda salsa SsNHXI and Arabidopsis AVP1 confer greater salt tolerance to transgenic rice than the single SsNHX1. Mol Breed 17:341-353.

1723 Zhao R, Dielen V, Kinet JM, Boutry M (2000) Cosuppression of a plasma membrane $\mathrm{H}^{+}$ATPase isoform impairs sucrose translocation, stomatal opening, plant growth and male fertility. Plant Cell 12:535-546.

1726 Zhao Y, Li H, Fang S, Kang Y, Wu W, et al. (2016) NONCODE 2016: an informative and valuable data source of long non-coding RNAs. Nucleic Acids Res 44:D203-D208.

1728 Zhen RG, Kin E, Rea PA (1997) The molecular and biochemical basis of pyrophophate1729 energised proton translocation at the vacuolar membrane. In: Leigh RA, Sanders D, (eds)

1731 Zhou H, Liu B, Weeks DP, Spalding MH, Yang B (2014) Large chromosomal deletions and 1732 heritable small genetic changes induced by CRISPR/Cas9 in rice. Nucleic Acids Res 1733 42:10903-10914. 
1734 Zielezinski A, Dolata J, Alaba S, Kruszka K, Pacak A, et al. (2015) mirEX 2.0-an integrated 1735 environment for expression profiling of plant microRNAs. BMC Plant Biol 15:144.

1736

1737 
Table 1. Single ion transporter genes (from glycophyte sources) recently genetically engineered to improve salt tolerance.

\begin{tabular}{|c|c|c|c|}
\hline Source organism & Gene & Transgenic host (additional information) & Reference \\
\hline \multicolumn{4}{|c|}{ Plasma membrane bound high-affinity potassium $\left(\mathrm{K}^{+}\right)$transporter $(\mathrm{HKT})$} \\
\hline \multirow[t]{2}{*}{ Arabidopsis thaliana } & AtHKT1;1 & $\begin{array}{l}\text { Arabidopsis thaliana (specific expression in } \\
\text { root cortex and epidermis cells) }\end{array}$ & Plett et al. (2010) \\
\hline & & $\begin{array}{l}\text { Oryza sativa (specific expression in root } \\
\text { cortex and epidermis cells) }\end{array}$ & Plett et al. (2010) \\
\hline Hordeum vulgare & $H v H K T 2 ; 1$ & Hordeum vulgare (overexpression) & Mian et al. (2011) \\
\hline \multirow[t]{2}{*}{$\begin{array}{l}\text { Triticum turgidum ssp. Durum } \\
\text { (original source: T. monococcum) }\end{array}$} & $\begin{array}{l}\text { TmHKT7 a.k.a. } \\
\text { TmHKT1;4-A2 }\end{array}$ & Triticum aestivum & James et al. (2011) \\
\hline & $\begin{array}{l}\text { TmHKT8 a.k.a. } \\
\text { TmHKT1;5-A }\end{array}$ & Triticum aestivum & James et al. (2011) \\
\hline Oryza sativa cv. Indica & $\begin{array}{l}\text { OsHKT1;1 and its } \\
\text { promoter }\end{array}$ & Oryza sativa cv. japonica & Campbell et al. (2017) \\
\hline Glycine max & GmHKT1;4 & Nicotiana tabacum & Chen et al. (2014) \\
\hline Triticum monococcum & $\operatorname{TmHKT1;5-A}$ & Triticum turgidum ssp. durum & Munns et al. (2012) \\
\hline \multicolumn{4}{|c|}{ Plasma membrane bound $\mathrm{Na}^{+}$insensitive $\mathrm{K}^{+}$transporter } \\
\hline Oryza sativa cv. Nipponbare & OsHAK5 & Nicotiana tabacum cv. BY2 cells & Horie et al. (2011) \\
\hline \multicolumn{4}{|c|}{ Plasma membrane $\mathrm{Na}^{+} / \mathrm{H}^{+}$antiporter system } \\
\hline \multirow[t]{2}{*}{ Arabidopsis thaliana } & AtSOS1 & Arabidopsis thaliana (overexpression) & Yang et al. (2009) \\
\hline & & Nicotiana tabacum cv. Xanthi-nc & Yue et al. (2012) \\
\hline \multirow[t]{2}{*}{ Artemisia japonica } & AjSOS1 & Chrysanthemum morifolium & Gao et al. (2016) \\
\hline & & Arabidopsis thaliana & Gao et al. (2016) \\
\hline \multirow[t]{2}{*}{ Chrysanthemum crissum } & $\operatorname{CcSOS} 1$ & Chrysanthemum morifolium & $\begin{array}{l}\text { An et al. (2014a); Gao et al. } \\
\text { (2016) }\end{array}$ \\
\hline & & Arabidopsis thaliana & Gao et al. (2016) \\
\hline \multirow[t]{2}{*}{ Chrysanthemum morifolium } & CmSOS1 & $\begin{array}{l}\text { Chrysanthemum morifolium } \\
\text { (overexpression) }\end{array}$ & Gao et al. (2016) \\
\hline & & Arabidopsis thaliana & Gao et al. (2016) \\
\hline \multirow[t]{2}{*}{ Crossostephium chinense } & CrcSOS1 & Chrysanthemum morifolium & Gao et al. (2016) \\
\hline & & Arabidopsis thaliana & Gao et al. (2016) \\
\hline Gossypium hirsutum & GhSOS1 & Arabidopsis thaliana & Chen et al. (2017) \\
\hline Sorghum bicolor & $S b N H X L P$ & Solanum lycopersicum & Kumari et al. (2017) \\
\hline \multicolumn{4}{|c|}{ Plasma membrane $\mathrm{Na}^{+}$pumping ATPase } \\
\hline Physcomitrella patens & PpENA1 & Oryza sativa & Jacobs et al. (2011) \\
\hline \multicolumn{4}{|c|}{ NHX-type vacuolar $\mathrm{Na}^{+}\left(\mathrm{K}^{+}\right) / \mathbf{H}^{+}$antiporter } \\
\hline Arachis hypogaea & AsNHX1 & Nicotiana tabacum & Zhang et al. (2017) \\
\hline Arabidopsis thaliana & AtNHX1 & Actinidia deliciosa & Tian et al. (2011) \\
\hline
\end{tabular}




\begin{tabular}{|c|c|c|c|}
\hline & & Arabidopsis thaliana (overexpression) & Liu et al. (2010) \\
\hline & & Arachis hypogaea & Asif et al. (2011) \\
\hline & AtNHX3 & Beta vulgaris & Liu et al. (2008) \\
\hline Hordeum vulgare & $H v N H X 2$ & Solanum tuberosum & Bayat et al. (2010) \\
\hline \multirow[t]{2}{*}{ Malus domestica } & $M d N H X 1$ & $\begin{array}{l}\text { Malus domestica (overexpression in } \\
\text { rootstocks of grafted plants or in calli, } \\
\text { respectively) }\end{array}$ & $\begin{array}{l}\text { Li et al. (2010), (2013); } \\
\text { Sun et al. (2017) }\end{array}$ \\
\hline & & Arabidopsis thaliana & Sun et al. (2017) \\
\hline Solanum torvum & StNHX1 & Glycine $\max$ & Chen et al. (2014) \\
\hline Triticum aestivum & TaNHX3 & Nicotiana tabacum & Lu et al. (2014) \\
\hline Vigna radiata & $\operatorname{VrNHX1}$ & Arabidopsis thaliana & Mishra et al. (2014) \\
\hline \multicolumn{4}{|c|}{ NHX-type endosomal $\mathrm{K}^{+} / \mathrm{H}^{+}$antiporter } \\
\hline \multirow[t]{2}{*}{ Solanum lycopersicum } & LeNHX2 & Arabidopsis thaliana & Rodriguez-Rosales et al. (2008) \\
\hline & & Solanum lycopersicum (overexpression) & Huertás et al. (2013) \\
\hline \multirow[t]{3}{*}{ Triticum aestivum } & TaNHX2 & Glycine $\max$ & Cao et al. (2011) \\
\hline & & Solanum lycopersicum & Yarra et al. (2012) \\
\hline & & Medicago sativa & Zhang et al. (2012) \\
\hline \multicolumn{4}{|c|}{ Vacuolar $\mathrm{H}^{+}$-ATPase subunits } \\
\hline Iris lactea & $\operatorname{IrlVHA}-c$ (C subunit) & Nicotiana tabacum & Wang et al. (2016) \\
\hline Limonium bicolor & LbVHA-cl (C1 subunit) & Nicotiana tabacum & Xu et al. (2011) \\
\hline Malus domestica & $M d V H A-A$ & Nicotiana tabacum & Dong et al. (2015) \\
\hline \multirow[t]{3}{*}{ Triticum aestivum } & $T a V B$ (B subunit) & Arabidopsis thaliana & Wang et al. (2011) \\
\hline & $\begin{array}{l}W 36 \text { (putative E } \\
\text { subunit) }\end{array}$ & Arabidopsis thaliana & Zhang et al. (2014c) \\
\hline & Several subunit genes & Arabidopsis thaliana & He et al. (2014) \\
\hline \multicolumn{4}{|c|}{ Vacuolar $\mathbf{H}^{+}$-pyrophosphatase } \\
\hline \multirow[t]{6}{*}{ Arabidopsis thaliana } & $A V P 1$ & Agrostis stolonifera L. & Li et al. (2010) \\
\hline & & Arabidopsis thaliana (overexpression) & Undurraga et al. (2012) \\
\hline & & Arachis hypogaea & Qin et al. (2013) \\
\hline & & Gossypium hirsutum & Pasapula et al. (2011) \\
\hline & & Hordeum vulgare & Schilling et al. (2014) \\
\hline & & Saccharum officinarum & Kumar et al. (2014) \\
\hline Populus trichocarpa & PtVP1.1 & Populus davidiana $\times$ P. bolleana & Yang et al. (2015) \\
\hline Sorghum bicolor & SbVPPase & Eleusine coracana & Anjaneyulu et al. (2014) \\
\hline
\end{tabular}


Table 2. Two or more ion transporter genes simultaneously genetically engineered to improve salt tolerance.

\begin{tabular}{|c|c|c|c|}
\hline Targets/Genes & Source organism(s) (genes) & Transgenic host & Reference \\
\hline $\begin{array}{l}\text { Plasma membrane } \mathrm{Na}^{+} / \mathrm{H}^{+} \text {antiporter } \\
\text { and } \mathrm{NHX} \text {-type vacuolar } \mathrm{Na}^{+} / \mathrm{H}^{+} \\
\text {antiporter }\end{array}$ & $\begin{array}{l}\text { Arabidopsis thaliana (co-overexpression of } \\
\text { AtSOS1 and AtNHXI) }\end{array}$ & Arabidopsis thaliana & Pehlivan et al. (2016) \\
\hline $\begin{array}{l}\text { Plasma membrane } \mathrm{Na}^{+} / \mathrm{H}^{+} \text {antiporter } \\
\text { 'system' }\end{array}$ & $\begin{array}{l}\text { Arabidopsis thaliana } \\
(\text { AtSOS } 1+A t S O S 2+\text { AtSOS } 3)\end{array}$ & Festuca arundinacea & Ma et al. (2014) \\
\hline $\begin{array}{l}\text { Plasma membrane } \mathrm{Na}^{+} / \mathrm{H}^{+} \text {antiporter } \\
\text { and a MYC-like bHLH transcriptional } \\
\text { activator }\end{array}$ & $\begin{array}{l}\text { - Chrysanthemum crassum (CcSOS1) } \\
\text { - and Chrysanthemum dichrum (CdICE1) }\end{array}$ & $\begin{array}{l}\text { Chrysanthemum } \\
\text { morifolium 'Jinba' }\end{array}$ & Song et al. (2014) \\
\hline \multirow{11}{*}{$\begin{array}{l}\mathrm{NHX} \text {-type vacuolar } \mathrm{Na}^{+} / \mathrm{H}^{+} \text {antiporter } \\
\text { and vacuolar } \mathrm{H}^{+} \text {-pyrophosphatase }\end{array}$} & Arabidopsis thaliana (AtNHX1 and AVP1) & Gossypium hirsutum & Shen et al. (2015) \\
\hline & $\begin{array}{l}\text { Pennisetum glaucum }(P g N H X 1) \text { and } \\
\text { Arabidopsis thaliana }(A V P 1)\end{array}$ & Solanum lycopersicum & $\begin{array}{l}\text { Bhaskaran and } \\
\text { Savithramma (2011) }\end{array}$ \\
\hline & Oryza sativa $(O s N H X 1$ and $O s V P 1)$ & $\begin{array}{l}\text { Oryza sativa } \\
\text { (overexpression) }\end{array}$ & Liu et al. (2010) \\
\hline & $\begin{array}{l}\text { Suaeda salsa }(S s N H X 1) \text { and Arabidopsis } \\
(\text { AVP1) }\end{array}$ & Oryza sativa & Zhao et al. (2006) \\
\hline & Suaeda corniculata (ScNHXI and ScVP) & Medicago sativa & Liu et al. (2013) \\
\hline & Triticum aestivum (TNHX1 and TVP1) & Arabidopsis thaliana & Brini et al. (2007) \\
\hline & Triticum aestivum (TNHXS1 and TVP1) & $\begin{array}{l}\text { Solanum lycopersicum } \\
\text { Nicotiana tabacum }\end{array}$ & $\begin{array}{l}\text { Khoudi et al. (2009) } \\
\text { Gouiaa et al. (2012) }\end{array}$ \\
\hline & & Solanum lycopersicum & $\begin{array}{l}\text { Gouiaa and Khoudi } \\
(2015)\end{array}$ \\
\hline & $\begin{array}{l}\text { Zygophyllum xanthoxylum (ZxNHX and } \\
\text { ZxVP1-1) }\end{array}$ & Beta vulgaris & Wu et al. (2015a) \\
\hline & & Lotus corniculatus & Bao et al. (2014) \\
\hline & & Medicago sativa & Bao et al. (2016) \\
\hline
\end{tabular}


Table 3. List of major databases/repositories and tools developed in recent years and available for prediction or identification of noncoding RNAs (including miRNAs) and their targets

\begin{tabular}{|c|c|c|c|}
\hline Database/ Tool & Description & Web link & Reference \\
\hline miRBase & $\begin{array}{l}\text { A biological database which acts as an archive of miRNA sequences } \\
\text { and annotations from more than } 220 \text { organisms including plants }\end{array}$ & http://www.mirbase.ogr/ & $\begin{array}{l}\text { Kozomara and } \\
\text { Griffiths-Jones } \\
(2014)\end{array}$ \\
\hline RNAcentral & $\begin{array}{l}\text { A ncRNA sequence database coordinated by European Bioinformatics } \\
\text { Institute and associated with } 25 \text { different databases }\end{array}$ & http://rnacentral.org/ & $\begin{array}{l}\text { RNAcentral } \\
\text { Consortium (2017) }\end{array}$ \\
\hline PMTED & A target expression prediction database exclusively for plant miRNAs & http:// pmted.agrinome.org/ & Sun et al. (2013) \\
\hline miRPlant & A program with tools to predict novel plant miRNAs & https://sourceforge.net/projects/mirplant/ & An et al. (2014) \\
\hline miRDeep-P & $\begin{array}{l}\text { A computational tool for analyzing the miRNA transcriptome in } \\
\text { plants. }\end{array}$ & https://sourceforge.net/projects/mirdp/ & Yang and Li (2011) \\
\hline P-SAMS & A plant sRNA maker site especially for amiRNAs and syn-tasiRNA & http://p-sams.carringtonlab.org & Fahlgren et al. (2016) \\
\hline PmiRKB & Plant miRNA knowledge base & http://bis.zju.edu.cn/pmirkb/ & Meng et al. (2010) \\
\hline NONCODE & $\begin{array}{l}\text { An integrated knowledge database dedicated to ncRNAs from various } \\
\text { organisms including Arabidopsis }\end{array}$ & $\underline{\text { http://www.noncode.org/ }}$ & Zhao et al. (2016) \\
\hline PNRD & $\begin{array}{l}\text { A plant ncRNA database with } 25739 \text { entries of } 11 \text { ncRNA-types from } \\
150 \text { plant species }\end{array}$ & $\begin{array}{l}\text { http://structuralbiology.cau.edu.cn/PNRD/index.p } \\
\underline{\mathrm{hp}}\end{array}$ & Yi et al. (2015) \\
\hline plantDARIO & $\begin{array}{l}\text { Web-based tools and platform for quantitative and qualitative analyses } \\
\text { of RNA-seq data in plants }\end{array}$ & http://snostrip.bioinf.uni-leipzig.de/index.py & Patra et al. (2014) \\
\hline miRge & Tool for processing sRNA-seq data to determine miRNA entropy & http://atlas.pathology.jhu.edu/baras/miRge.html. & Baras et al. (2015) \\
\hline PmiRExAt & $\begin{array}{l}\text { A database resource that provides plant miRNA expression profile and } \\
\text { query tool for } 1859 \text { wheat, } 2330 \text { rice and } 283 \text { maize miRNAs }\end{array}$ & $\underline{\text { http://pmirexat.nabi.res.in }}$ & Gurjar et al. (2016) \\
\hline miRPursuit & $\begin{array}{l}\text { A pipeline to provide running end-to-end analyses of high-throughput } \\
\text { sRNA-seq data in non-/model plants from known and novel } \\
\text { sequences }\end{array}$ & $\underline{\text { https://readthedocs.org/projects/mirpursuit/ }}$ & Chaves et al. (2017) \\
\hline $\operatorname{mirEX} 2.0$ & $\begin{array}{l}\text { A platform to explore plant miRNA expression data based on } \\
\text { qRTPCR and NGS }\end{array}$ & $\underline{\text { http://www.combio.pl/mirex }}$ & $\begin{array}{l}\text { Zielezinski et al. } \\
(2015)\end{array}$ \\
\hline miRA & A tool useful for identifying miRNA precursors in plants & $\underline{\text { https://github.com/mhuttner/miRA }}$ & Evers et al. (2015) \\
\hline miRandb & $\begin{array}{l}\text { miRNA algorithmic network database, a meta-database offering online } \\
\text { services for miRNA research }\end{array}$ & http://mirandd.ir & $\begin{array}{l}\text { Aghaee-Bakhtiari et } \\
\text { al. (2017) }\end{array}$ \\
\hline
\end{tabular}


Table 4. Halophytes as sources of genes for enhanced salt-tolerance in glycophytes.

\begin{tabular}{|c|c|c|c|c|}
\hline Donor halophyte & Gene & Description & Transformed glycophyte & Reference \\
\hline $\begin{array}{l}\text { Aeluropus littoralis } \\
\text { Ammopiptanthus } \\
\text { mongolicus }\end{array}$ & $\begin{array}{l}\text { AlNHX1 } \\
\text { AmVP1 }\end{array}$ & $\begin{array}{l}\text { Vacuolar } \mathrm{Na}^{+} / \mathrm{H}^{+} \text {antiporter } \\
\text { Vacuolar } \mathrm{H}^{+} \text {-pump }\end{array}$ & $\begin{array}{l}\text { Nicotiana tabacum } \\
\text { Arabidopsis thaliana }\end{array}$ & $\begin{array}{l}\text { Zhang et al. (2008) } \\
\text { Wei et al. (2012) }\end{array}$ \\
\hline Atriplex dimorphostegia & AdNHX1 & Vacuolar $\mathrm{Na}^{+} / \mathrm{H}^{+}$antiporter & Oryza sativa & Li et al. (2008) \\
\hline $\begin{array}{l}\text { Atriplex gmelini } \\
\text { Atriplex hortensis } \\
\text { Chenopodium glaucum } \\
\text { Chloris virgata }\end{array}$ & $\begin{array}{l}\text { AgNHX1 } \\
\text { AhBADH } \\
\text { CgNHX1 } \\
\text { CvPMA } \triangle C \\
\text { HcNHX1 }\end{array}$ & $\begin{array}{l}\text { Vacuolar } \mathrm{Na}^{+} / \mathrm{H}^{+} \text {antiporter } \\
\text { Synthesis of glycine betaine } \\
\text { Vacuolar } \mathrm{Na}^{+} / \mathrm{H}^{+} \text {antiporter } \\
\text { Plasma membrane } \mathrm{H}^{+} \text {-ATPase } \\
\text { Vacuolar } \mathrm{Na}^{+} / \mathrm{H}^{+} \text {antiporter }\end{array}$ & $\begin{array}{l}\text { Oryza sativa } \\
\text { Nicotiana tabacum } \\
\text { Oryza sativa } \\
\text { Arabidopsis thaliana } \\
\text { Arabidopsis thaliana }\end{array}$ & $\begin{array}{l}\text { Ohta et al. (2002) } \\
\text { Jia et al. (2002) } \\
\text { Li et al. (2008) } \\
\text { Zhang et al. (2014a) } \\
\text { Guan et al. (2011) }\end{array}$ \\
\hline Halostachys caspica & $\begin{array}{l}\text { HcVHA-B } \\
\text { HcVP1 }\end{array}$ & $\begin{array}{l}\text { Vacuolar } \mathrm{H}^{+} \text {-ATPase, subunit } \\
\text { B } \\
\text { Vacuolar } \mathrm{H}^{+} \text {-pump }\end{array}$ & $\begin{array}{l}\text { Arabidopsis thaliana } \\
\text { Arabidopsis thaliana }\end{array}$ & $\begin{array}{l}\text { Hu et al. (2012) } \\
\text { Hu et al. (2012) }\end{array}$ \\
\hline $\begin{array}{l}\text { Kalidium foliatum } \\
\text { Pennisetum glaucum }\end{array}$ & $\begin{array}{l}\text { KfVP1 } \\
\text { PgNHX1 }\end{array}$ & $\begin{array}{l}\text { Vacuolar } \mathrm{H}^{+} \text {-pump } \\
\text { Vacuolar } \mathrm{Na}^{+} / \mathrm{H}^{+} \text {antiporter }\end{array}$ & $\begin{array}{l}\text { Arabidopsis thaliana } \\
\text { Arabidopsis thaliana } \\
\text { Brassica juncea } \\
\text { Oryza sativa }\end{array}$ & $\begin{array}{l}\text { Hu et al. (2012) } \\
\text { Yao et al. (2012) } \\
\text { Rajagopal et al. (2007) } \\
\text { Verma et al. (2007) }\end{array}$ \\
\hline \multirow{6}{*}{ Puccinellia tenuifolia } & PutAKT1 & $\begin{array}{l}\text { Plasma membrane located } \mathrm{K}^{+} \\
\text {inward rectifying channel } \\
(\mathrm{KIRC})\end{array}$ & Arabidopsis thaliana & Ardie et al. (2010) \\
\hline & PtNHA1 & $\begin{array}{l}\text { Plasma membrane } \mathrm{Na}^{+} / \mathrm{H}^{+} \\
\text {antiporter }\end{array}$ & Arabidopsis thaliana & Wang et al. (2011) \\
\hline & PutNHX & Vacuolar $\mathrm{Na}^{+} / \mathrm{H}^{+}$antiporter & Oryza sativa & Kobayashi et al. (2012) \\
\hline & SbMYB15 & $\begin{array}{l}\text { R2R3-type transcription factor } \\
\text { (TF) }\end{array}$ & Nicotiana tabacum & Shukla et al. (2015) \\
\hline & SbASR1 & Abscisic acid stress ripening-1 & $\begin{array}{l}\text { Arachis hypogea } \\
\text { Jatropha curcas }\end{array}$ & $\begin{array}{l}\text { Tiwari et al. (2015) } \\
\text { Jha et al. (2013) }\end{array}$ \\
\hline & $\mathrm{SbNHX1}$ & Vacuolar $\mathrm{Na}^{+} / \mathrm{H}^{+}$antiporter & $\begin{array}{l}\text { Ricinus communis } \\
\text { Cuminum cyminum }\end{array}$ & $\begin{array}{l}\text { Patel et al. (2015) } \\
\text { Pandey et al. (2016) }\end{array}$ \\
\hline \multirow[t]{4}{*}{ Salicornia brachiata } & SbpAPX & $\begin{array}{l}\text { Peroxisomal ascorbate } \\
\text { peroxidase }\end{array}$ & Nicotiana tabacum & Singh et al. (2014) \\
\hline & SbpAPX & $\begin{array}{l}\text { Peroxisomal ascorbate } \\
\text { peroxidase }\end{array}$ & Arachis hypogea & Singh et al. (2014) \\
\hline & SbSDR1 & $\begin{array}{l}\text { Salt and drought responsive } \\
\text { gene }\end{array}$ & Nicotiana tabacum & Singh et al. (2016) \\
\hline & SbSOS1 & $\begin{array}{l}\text { Plasma membrane } \mathrm{Na}^{+} / \mathrm{H}^{+} \\
\text {antiporter }\end{array}$ & Nicotiana tabacum & Yadav et al. (2012) \\
\hline
\end{tabular}




\begin{tabular}{|c|c|c|c|c|}
\hline Salicornia europaea & SeNHX1 & Vacuolar $\mathrm{Na}^{+} / \mathrm{H}^{+}$antiporter & Medicago sativa & Zhang et al. (2014c) \\
\hline Salix matsudana & SmQR & Quinone reductase & Arabidopsis thaliana & Song et al. (2016) \\
\hline Salsola soda & SsNHX1 & Vacuolar $\mathrm{Na}^{+} / \mathrm{H}^{+}$antiporter & Medicago sativa & Li et al. (2011) \\
\hline \multirow[t]{2}{*}{ Sesuvium portulacastrum } & SpAQP1 & Aquaporin gene & Nicotiana tabacum & Chang et al. (2016) \\
\hline & SpAHA1 & Plasma membrane $\mathrm{H}^{+}$-ATPase & Arabidopsis thaliana & Fan et al. (2018) \\
\hline Spartina alterniflora & SaVHAc1 & $\begin{array}{l}\text { Vacuolar } \mathrm{H}^{+} \text {-ATPase subunit } \\
\text { c1 }\end{array}$ & Oryza sativa & Baisakh et al. (2012) \\
\hline Suaeda liaotungensis & SIBADH & $\begin{array}{l}\text { Betaine aldehyde } \\
\text { dehydrogenase }\end{array}$ & Zea mays & Wu et al. (2008) \\
\hline \multirow{3}{*}{ Suaeda corniculata } & SINAC & NAC transcription factor & Arabidopsis thaliana & Li et al. (2014) \\
\hline & $\mathrm{ScBADH}$ & $\begin{array}{l}\text { Betaine aldehyde } \\
\text { dehydrogenase }\end{array}$ & Arabidopsis thaliana & Wang et al. (2016) \\
\hline & ScVP & Vacuolar $\mathrm{H}^{+}$-pump & Arabidopsis thaliana & Liu et al. (2011) \\
\hline \multirow{3}{*}{ Suaeda salsa } & SsCAX1 & $\begin{array}{l}\text { Vacuolar } \mathrm{H}^{+} / \mathrm{Ca}^{2+} \text { transporter } \\
\text { Dehydration-responsive }\end{array}$ & Arabidopsis thaliana & Han et al. (2012) \\
\hline & SsDREB & $\begin{array}{l}\text { element-binding (DREB) } \\
\text { transcription factor }\end{array}$ & Nicotiana tabacum & Zhang et al. (2015) \\
\hline & Ss.sAPX & Stroma ascorbate peroxidase & Arabidopsis thaliana & Li et al. (2012) \\
\hline \multirow[t]{2}{*}{ Tamarix androssowii } & TaMnSOD & $\begin{array}{l}\text { Manganese superoxide } \\
\text { dismutase }\end{array}$ & $\begin{array}{l}\text { Populus davidiana } \times P . \\
\text { bolleana }\end{array}$ & Wang et al. (2010) \\
\hline & TsNHX1 & Vacuolar $\mathrm{Na}^{+} / \mathrm{H}^{+}$antiporter & Arabidopsis thaliana & Wu et al. (2009) \\
\hline \multirow[t]{3}{*}{ Thellungiella salsuginea } & TsLEA1 & $\begin{array}{l}\text { Late embryogenesis abundant } \\
\text { (LEA) }\end{array}$ & Arabidopsis thaliana & Zhang et al. (2012) \\
\hline & TsTIP1 & Tonoplast aquaporin gene & Arabidopsis thaliana & Wang et al. (2014) \\
\hline & ThSOS1 & $\begin{array}{l}\text { Plasma membrane } \mathrm{Na}^{+} / \mathrm{H}^{+} \\
\text {antiporter }\end{array}$ & Arabidopsis thaliana & Oh et al. (2009) \\
\hline Zoysia matrella & $\mathrm{ZmVP1}$ & $\begin{array}{l}\text { Vacuolar } \mathrm{H}^{+} \text {-pyrophosphatase } \\
\text { (VP) }\end{array}$ & Arabidopsis thaliana & Chen et al. (2015) \\
\hline
\end{tabular}


Table 5. Additional sources of genes (from halobionts) for enhanced salt-tolerance in glycophytes.

\begin{tabular}{|c|c|c|c|c|c|}
\hline Donor type & Organism & Gene & Transformed glycophyte & Improved character/s & References \\
\hline $\begin{array}{l}\text { Halotolerant } \\
\text { cyanobacterium }\end{array}$ & $\begin{array}{l}\text { Aphanothece } \\
\text { halophytica }\end{array}$ & $\begin{array}{l}\text { ApGSMT and } \\
\text { ApDMT }\end{array}$ & $\begin{array}{l}\text { Oryza sativa L., cv. } \\
\text { Nipponbare }\end{array}$ & $\begin{array}{l}\text { Enhancement in glycine betaine } \\
\text { synthesis, improved growth and survival } \\
\text { rate during stress as well as recovery } \\
\text { stage }\end{array}$ & Niu et al. (2014) \\
\hline Halophilic bacterium & $\begin{array}{l}\text { Halomonas } \\
\text { elongata }\end{array}$ & $\begin{array}{l}\text { HeectA, } \\
\text { HeectB and } \\
\text { HeectC }\end{array}$ & $\begin{array}{l}\text { Lycopersicon esculentum } \\
\text { cv. 'Momotaro' and } \\
\text { cv. 'Saturn' }\end{array}$ & $\begin{array}{l}\text { Increased accumulation of ectoine, } \\
\text { improved dry weight values and } \\
\text { photosynthetic rate, decreased } \\
\text { accumulation of MDA in leaves }\end{array}$ & Moghaieb et al. (2011) \\
\hline Halophilic archaeon & $\begin{array}{l}\text { Natrinema } \\
\text { altunense }\end{array}$ & NaMnSOD & $\begin{array}{l}\text { Oryza sativa L., cv. } \\
\text { Nipponbare }\end{array}$ & $\begin{array}{l}\text { Increased SOD and CAT activities, } \\
\text { reduced superoxide radical and hydrogen } \\
\text { peroxide levels, reduced ion leakage and } \\
\text { MDA content }\end{array}$ & Chen et al. (2013) \\
\hline \multirow[t]{2}{*}{ Halophilic fungi } & $\begin{array}{l}\text { Aspergillus } \\
\text { glaucus }\end{array}$ & AgRPS3aE & $\begin{array}{l}\text { Arabidopsis thaliana } \\
\text { (Columbia-0) } \\
\text { Nicotiana tabacum cv. } \\
\text { SR-1 }\end{array}$ & Increased leaf area and root length & Liang et al. (2015) \\
\hline & $\begin{array}{l}\text { Aspergillus } \\
\text { glaucus }\end{array}$ & AgRPL44 & Nicotiana tabacum & Increased root length, fresh weight & Liu et al. (2014) \\
\hline \multirow[b]{2}{*}{ Halotolerant algae } & $\begin{array}{l}\text { Dunaliella salina } \\
\text { strain Y6 }\end{array}$ & $\begin{array}{l}\text { Ds-A3-3 and } \\
\text { Ds-26-16 }\end{array}$ & Nicotiana tabacum & $\begin{array}{l}\text { Increased leaf area, root length, enhanced } \\
\text { level of SOS gene expression }\end{array}$ & Gong et al. (2014) \\
\hline & $\begin{array}{l}\text { Chlamydomonas } \\
\text { strain W80 }\end{array}$ & $\begin{array}{l}\text { GPX-like } \\
\text { protein cDNAs } \\
\text { (GPX and GPX) }\end{array}$ & $\begin{array}{l}\text { Nicotiana tabacum cv. } \\
\text { Xanthi }\end{array}$ & $\begin{array}{l}\text { Increased tolerance against oxidative and } \\
\text { salt stress with reduced lipid peroxidation } \\
\text { and increased photosynthetic and } \\
\text { antioxidative system }\end{array}$ & Yoshimura et al. (2003) \\
\hline
\end{tabular}




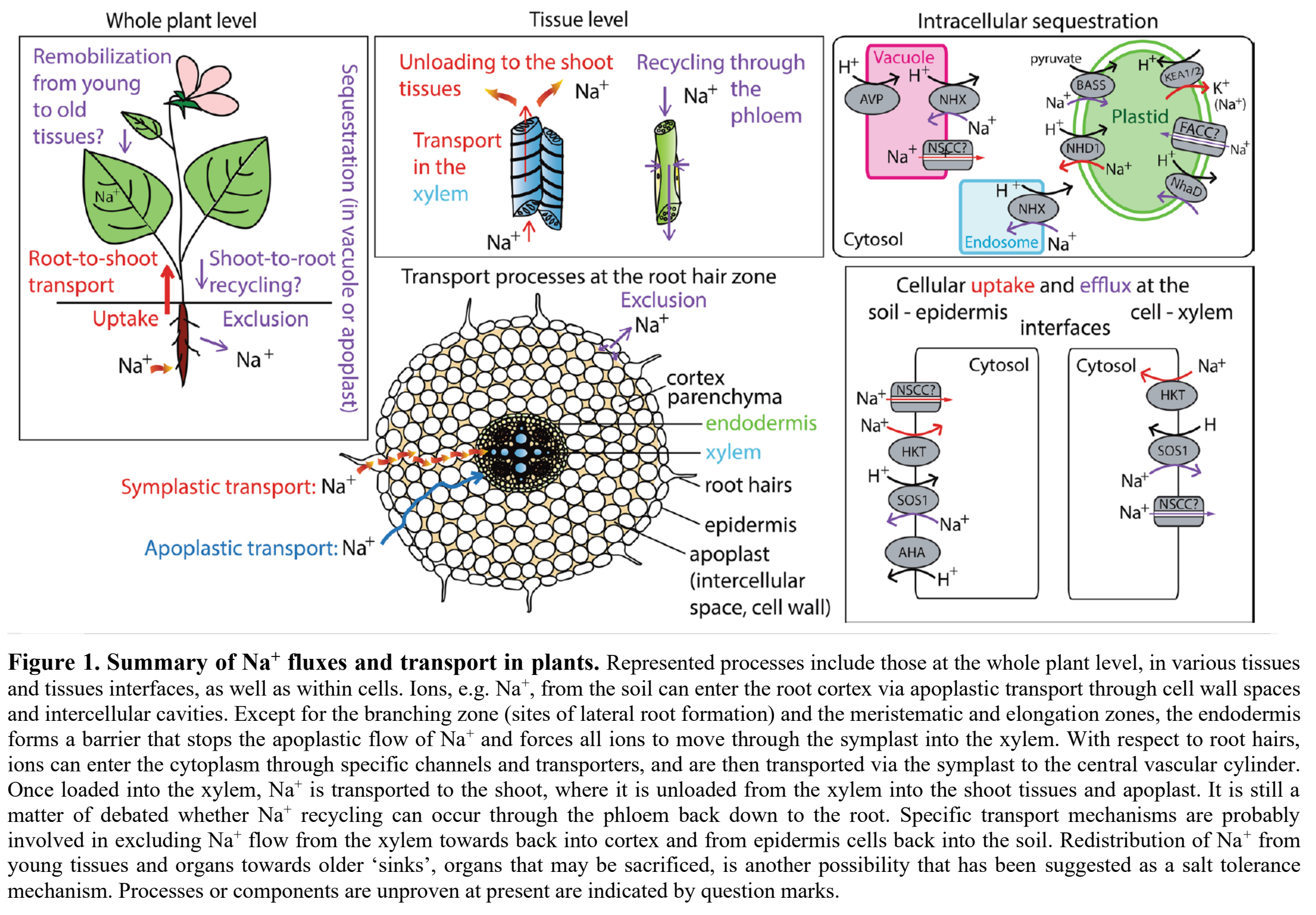


Figure 2. Selected salt responsive plant miRNAs, their targets and the traits regulated by these miRNAs (summary diagram showing information obtained from important crops including Oryza sativa, Zea mays, Triticum aestivum, Hordeum vulgare, Glycine max, Solanum tuberosum, and Solanum lycopersicum).

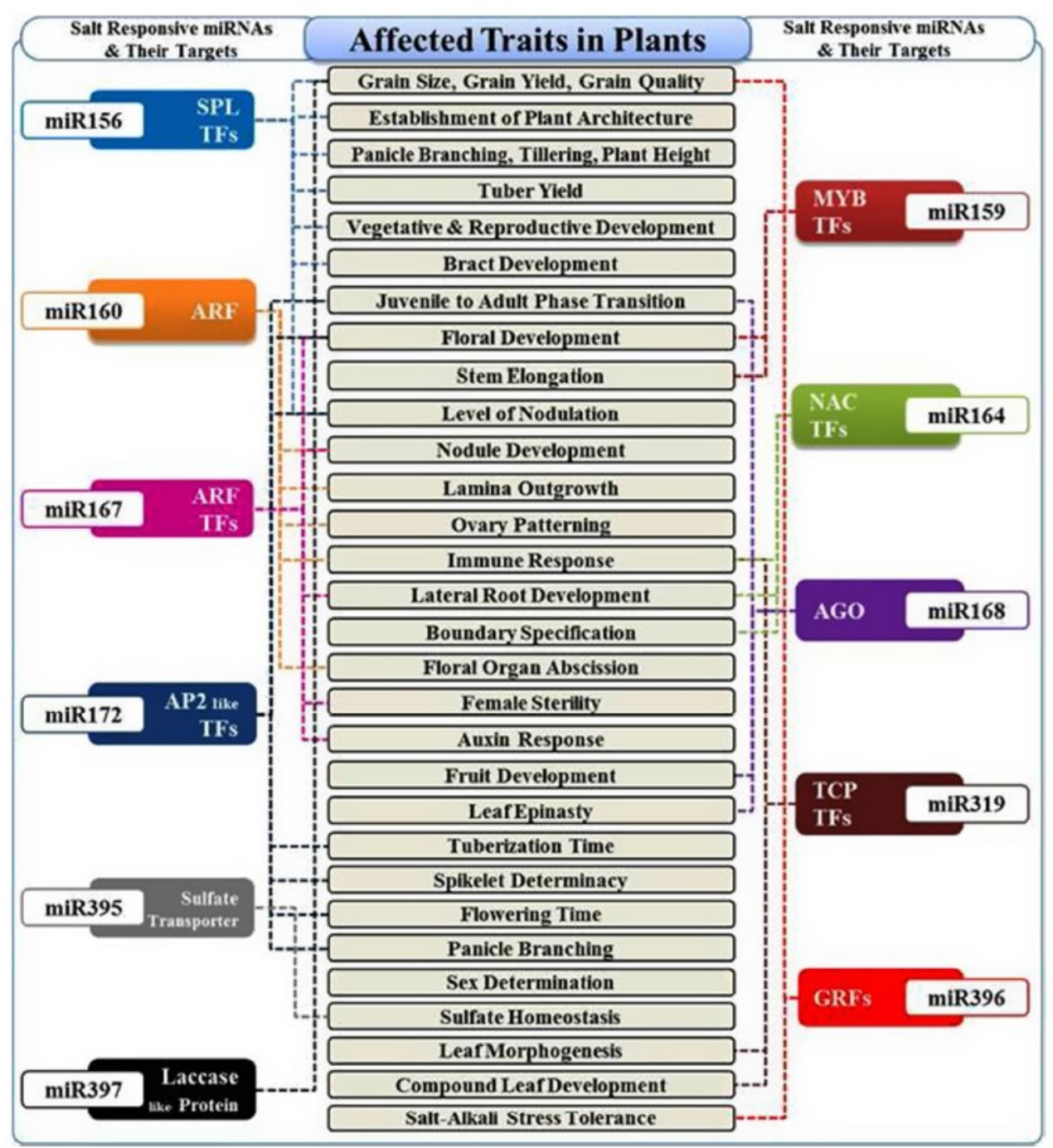


